\title{
Generalized Synthesis of Uniform Metal Nanoparticles Assisted with Tungsten Hexacarbonyl
}

Xixia Zhao ${ }^{1,2, \#,}$ Qian Di,2,\#, Mingrui Li ${ }^{1}$, Qi Yang ${ }^{1}$, Ziyun Zhang ${ }^{1}$, Xinyang Guo , Xiaokun Fan ${ }^{1}$, Kerong Deng ${ }^{1}$,Wen Chen ${ }^{1}$, Jun Zhang ${ }^{2}$, Jiye Fang ${ }^{3}$, and Zewei Quan*,1

${ }^{1}$ Department of Chemistry, Southern University of Science and Technology (SUSTech), Shenzhen, Guangdong 518055, China

${ }^{2}$ State Key Laboratory of Heavy Oil Processing, College of Chemical Engineering, China University of Petroleum, Qingdao, Shandong 266580, China

${ }^{3}$ Department of Chemistry, State University of New York at Binghamton, Binghamton, New York 13902, United States

\# equal contribution

*E-mail: quanzw@sustech.edu.cn 


\section{Experimental Section}

Chemicals. Silver nitrate $\left(\mathrm{AgNO}_{3}, 99.99 \%\right)$, gold(III) chloride trihydrate $\left(\mathrm{HAuCl}_{4} \cdot 3 \mathrm{H}_{2} \mathrm{O}, \geq 49.0 \%\right.$ Au basis), palladium(II) acetylacetonate $\left(\mathrm{Pd}(\mathrm{acac})_{2}, 99 \%\right)$, hexamethyldisilazane (HMDS, 99\%), oleylamine (OAm, 70\%), 1-octadecene (ODE, 90\%), oleic acid (OA, 90\%), 1-dodecanethiol (DDT, 98\%), and tri-n-octylphosphine (TOP, 97\%) were purchased from Sigma-Aldrich. Hexacarbonyl tungsten (W(CO) 97\%), copper acetylacetonate $\left(\mathrm{Cu}(\mathrm{acac})_{2}, 99 \%\right)$, and indium(III) acetate $\left(\mathrm{In}\left(\mathrm{CH}_{3} \mathrm{COO}\right)_{3}, 99.999 \%\right)$ were purchased from Alfa Aesar. Iron(II) chloride tetrahydrate $\left(\mathrm{FeCl}_{2} \bullet 4 \mathrm{H}_{2} \mathrm{O}, 99.95 \%\right)$, lead(II) bromide $\left(\mathrm{PbBr}_{2}, \quad 99 \%\right)$ and 1,12-diaminododecane (DDA, 98\%) were purchased from Aladdin. Cobalt(II) acetate tetrahydrate $\left(\mathrm{Co}\left(\mathrm{CH}_{3} \mathrm{COO}\right)_{2} \bullet 4 \mathrm{H}_{2} \mathrm{O}, 99.5 \%\right)$ and nickel(II) acetate tetrahydrate $\left(\mathrm{Ni}\left(\mathrm{CH}_{3} \mathrm{COO}\right)_{2} \bullet 4 \mathrm{H}_{2} \mathrm{O}, 98 \%\right)$ were purchased from Sinopharm Chemical Reagent Co., Ltd. Germanium diiodide $\left(\mathrm{GeI}_{2}, 99.99 \%\right)$ was purchased from Strem. OAm and ODE were dried by heating at $120^{\circ} \mathrm{C}$ under vacuum for $1 \mathrm{~h}$ and then stored under the argon atmosphere prior to use, and all other reagents were used as received.

Synthesis of Ag nanoparticles. Ag with different sizes $(4.9 \mathrm{~nm}, 10.8 \mathrm{~nm}$, and 16.9 $\mathrm{nm}$ ) can be synthesized by adjusting the capping ligand such as OAm, TOP, and DDT. For $16.9 \mathrm{~nm} \mathrm{Ag}$ nanoparticles, $1 \mathrm{~mL}$ of OAm, $1 \mathrm{~mL}$ of TOP, $20 \mathrm{~mL}$ of ODE, 40 $\mathrm{mg}$ of $\mathrm{AgNO}_{3}$, and $50 \mathrm{mg}$ of $\mathrm{W}(\mathrm{CO})_{6}$ were added into a three-neck round-bottom flask equipped with a condenser and a thermometer under argon flow. The mixture was then heated to $240{ }^{\circ} \mathrm{C}$ and kept for $1 \mathrm{~h}$ with vigorous stirring under an argon stream. The resultant products were isolated by centrifugation and washed with anhydrous hexane and anhydrous ethanol for several times. The Ag nanoparticles were finally redispersed in hexane, forming a colloidal suspension. In order to obtain $10.8 \mathrm{~nm}$ and $4.9 \mathrm{~nm} \mathrm{Ag}, 1 \mathrm{~mL}$ of TOP was removed and $0.1 \mathrm{~mL}$ of DDT were added, respectively. The solution volume was kept constant by adjusting the amount of ODE in these syntheses.

Synthesis of Au nanoparticles. The Au-OAm precursor was first prepared by adding $20 \mathrm{mg}$ of gold(III) chloride trihydrate into $4 \mathrm{~mL}$ of OAm in the glovebox. Then the mixture was slightly heated with magnetic stirring to enable complete dissolution. In a typical synthesis of Au nanoparticles, $50 \mathrm{mg}$ of $\mathrm{W}(\mathrm{CO})_{6}, 4 \mathrm{~mL}$ of OAm and $4 \mathrm{~mL}$ of OA were added into a three-neck round-bottom flask, respectively. After being degassed under vacuum, the mixture was heated to $130{ }^{\circ} \mathrm{C}$. Then, the Au-OAm precursor solution was quickly injected into the flask and then held for $30 \mathrm{~min}$. At last, the flask was treated with ice water to quench the reaction. The product was purified by centrifugation with hexane and ethanol, which is similar to that for $\mathrm{Ag}$ nanoparticles, and was finally dispersed in hexane.

Synthesis of Pd nanoparticles. In the formation of $12.7 \mathrm{~nm}$ Pd nanoparticles, $60 \mathrm{mg}$ of $\mathrm{W}(\mathrm{CO})_{6}$ was first mixed with $8 \mathrm{~mL}$ of ODE in a three-neck round-bottom flask with vigorous stirring and heated to $140{ }^{\circ} \mathrm{C}$. Next, $40 \mathrm{mg}$ of $\mathrm{Pd}(\mathrm{acac})_{2}$ mixed with 1 $\mathrm{mL}$ of $\mathrm{OAm}$ and $1 \mathrm{~mL}$ of ODE were injected immediately. Then, the solution temperature was raised to $180{ }^{\circ} \mathrm{C}$ and kept for $30 \mathrm{~min}$. At last, the solution was quickly cooled down by ice water. For the synthesis of $4.6 \mathrm{~nm}$ Pd nanoparticles, 40 
$\mathrm{mg}$ of $\mathrm{Pd}(\mathrm{acac})_{2}$ was first mixed with $1 \mathrm{~mL}$ of OAm, $0.5 \mathrm{~mL}$ of TOP, and $1 \mathrm{~mL}$ of ODE. Next, $60 \mathrm{mg}$ of $\mathrm{W}(\mathrm{CO})_{6}$ was mixed with $8 \mathrm{~mL}$ of ODE in a three-neck flask with vigorous stirring and heated to $180{ }^{\circ} \mathrm{C}$. Then, the as-prepared $\mathrm{Pd}$ precursor solution was injected immediately. The temperature was raised to $240{ }^{\circ} \mathrm{C}$ and kept for $30 \mathrm{~min}$. For the synthesis of $2.6 \mathrm{~nm}$ Pd nanoparticles, $0.1 \mathrm{~mL}$ of TOP was used and other experimental conditions were kept the same as for $4.6 \mathrm{~nm}$ Pd nanoparticles. The purification processes were similar to Ag nanoparticles.

Synthesis of Ni nanoparticles. The Ni-(II)-OAm solution was prepared first: $71 \mathrm{mg}$ of $\mathrm{Ni}\left(\mathrm{CH}_{3} \mathrm{COO}\right)_{2} \cdot 4 \mathrm{H}_{2} \mathrm{O}$ and $8 \mathrm{~mL}$ of OAm were placed into a $100 \mathrm{~mL}$ vial, which was sealed and vacuumed at $150{ }^{\circ} \mathrm{C}$ for about $30 \mathrm{~min}$. In the synthesis of $7.9 \mathrm{~nm} \mathrm{Ni}$ nanoparticles, $50 \mathrm{mg}$ of $\mathrm{W}(\mathrm{CO})_{6}$ was added to a $100 \mathrm{~mL}$ three-neck round-bottom flask and then degassed under vacuum at ambient temperature for 5-10 min. Next, under a constant flow of argon gas, the as-prepared Ni-(II)-OAm solution, $1 \mathrm{~mL}$ of ODE, and $3 \mathrm{~mL}$ of TOP were injected sequentially into the flask. The mixture was then quickly heated to $220{ }^{\circ} \mathrm{C}$ at $20{ }^{\circ} \mathrm{C} / \mathrm{min}$ and held for $40 \mathrm{~min}$. The remaining procedures were similar to that for $\mathrm{Ag}$ nanoparticles. For $13.0 \mathrm{~nm}$ Ni nanoparticles, 2 $\mathrm{mL}$ of ODE and $2 \mathrm{~mL}$ of TOP were used and other conditions were same as that of $7.9 \mathrm{~nm}$ Ni nanoparticles.

Synthesis of Co nanoparticles. In the synthesis of $8.5 \mathrm{~nm}$ Co nanoparticles, $50 \mathrm{mg}$ of $\mathrm{Co}\left(\mathrm{CH}_{3} \mathrm{COO}\right)_{2} \cdot 4 \mathrm{H}_{2} \mathrm{O}$ was placed into a $100 \mathrm{~mL}$ three-neck round-bottom flask and then degassed under vacuum at ambient temperature for 5-10 $\mathrm{min}$, followed by an addition of $9 \mathrm{~mL}$ of OAm. The mixture was vacuumed at $150{ }^{\circ} \mathrm{C}$ for about $20 \mathrm{~min}$. After $50 \mathrm{mg}$ of $\mathrm{W}(\mathrm{CO})_{6}$ and $1 \mathrm{~mL}$ of TOP were added under a constant flow of argon gas, the mixture was then quickly heated to $240{ }^{\circ} \mathrm{C}$ and held for $10 \mathrm{~min}$, forming a black solution. The reaction was quickly ceased with a cold water bath, purified with similar methods to Ag nanoparticles, and finally dispersed in hexane. In the synthesis of $13.4 \mathrm{~nm}$ Co nanoparticles, $80 \mathrm{mg}$ of $\mathrm{Co}\left(\mathrm{CH}_{3} \mathrm{COO}\right)_{2} \cdot 4 \mathrm{H}_{2} \mathrm{O}$ was used, together with $9 \mathrm{~mL}$ of OAm and $0.1 \mathrm{~mL}$ of OA in the first step. The reaction temperature was raised to $260{ }^{\circ} \mathrm{C}$ and held for $20 \mathrm{~min}$. The other experimental parameters were same as that of $8.5 \mathrm{~nm}$ Co nanoparticles.

Synthesis of Fe nanoparticles. The Fe-(II)-OAm solution was prepared in this procedure: $64 \mathrm{mg}$ of $\mathrm{FeCl}_{2} \bullet 4 \mathrm{H}_{2} \mathrm{O}$ was placed into a $100 \mathrm{~mL}$ vial followed by the addition of $9 \mathrm{~mL}$ of OAm, and then the vial was sealed and vacuumed at $150{ }^{\circ} \mathrm{C}$ for about $20 \mathrm{~min}$. In a typical preparation of Fe nanoparticles, $50 \mathrm{mg}$ of $\mathrm{W}(\mathrm{CO})_{6}$ was added to a $100 \mathrm{~mL}$ three-neck round-bottom and then was degassed under vacuum at room temperature for 5-10 min. Next, under a constant flow of argon gas, the as-prepared Fe-(II)-OAm solution and $0.5 \mathrm{~mL}$ of HMDS were injected sequentially into the reaction flask. The mixture was then quickly heated to $260^{\circ} \mathrm{C}$ at $20{ }^{\circ} \mathrm{C} / \mathrm{min}$ and held for $15 \mathrm{~min}$, forming a black solution. The reaction was quickly quenched with a cold water bath. These Fe nanoparticles were cleaned by using the similar procedure with Ag nanoparticles and finally dispersed in hexane to form a colloidal suspension for further characterizations.

Synthesis of $\mathrm{Cu}$ nanoparticles. The $\mathrm{Cu}$ precursor solution was first prepared by dissolving $70 \mathrm{mg}$ of $\mathrm{Cu}(\mathrm{acac})_{2}$ into $2 \mathrm{~mL}$ of $\mathrm{OAm}$ at $120^{\circ} \mathrm{C}$, forming a green clear 
solution. In the synthesis of $\mathrm{Cu}$ nanoparticles, $50 \mathrm{mg}$ of $\mathrm{W}(\mathrm{CO})_{6}, 8 \mathrm{~mL}$ of ODE, and $1.5 \mathrm{~mL}$ of TOP were added into a $100 \mathrm{~mL}$ three-neck round-bottom flask under argon flow, and then heated to $250{ }^{\circ} \mathrm{C}\left(10{ }^{\circ} \mathrm{C} / \mathrm{min}\right)$ with continuous magnetic stirring. The as-prepared $\mathrm{Cu}$ precursor solution was then injected into the flask and the mixture turned from colorless to dark brown quickly. Then, the mixture was kept at $250^{\circ} \mathrm{C}$ for 20 min, resulting in a reddish-brown solution. As the reaction ended, the flask was allowed to naturally cool down, and the rest procedure was similar to that for $\mathrm{Ag}$ nanoparticles.

Synthesis of In nanoparticles. The In precursor solution was prepared first: $10 \mathrm{mg}$ of $\mathrm{In}\left(\mathrm{CH}_{3} \mathrm{COO}\right)_{3}$ was mixed with $1 \mathrm{~mL}$ of HMDS in a $20 \mathrm{~mL}$ vial in the glovebox. Then $8 \mathrm{~mL}$ of OAm was also injected into the vial and heated to $100{ }^{\circ} \mathrm{C}$ in an oil bath to form a transparent solution. In the synthesis of $22.5 \mathrm{~nm}$ In nanoparticles, $50 \mathrm{mg}$ of $\mathrm{W}(\mathrm{CO})_{6}$ was firstly added into a $100 \mathrm{~mL}$ three-neck round-bottom flask, and then degassed under vacuum at ambient temperature for $10 \mathrm{~min}$. Next, the as-prepared In precursor solution was injected into the flask under constant argon flow. The mixture was then heated to $280{ }^{\circ} \mathrm{C}$ for $25 \mathrm{~min}$ and held for $15 \mathrm{~min}$. The other treatments were similar to that for Ag nanoparticles.

Synthesis of Ge nanoparticles. For the preparation of Ge precursor solution, $30 \mathrm{mg}$ of $\mathrm{GeI}_{2}$ was mixed with $8 \mathrm{~mL}$ of TOP, $1 \mathrm{~mL}$ of OAm (degassed at $120{ }^{\circ} \mathrm{C}$ for $1 \mathrm{~h}$ before use) and $1 \mathrm{~mL}$ of HMDS in the glovebox. In a typical synthesis of $6.0 \mathrm{~nm} \mathrm{Ge}$ nanoparticles, $10 \mathrm{mg}$ of $\mathrm{W}(\mathrm{CO})_{6}$ and $46.2 \mathrm{mg}$ of DDA were added into a $100 \mathrm{~mL}$ three-neck round-bottom flask, and then degassed for $1 \mathrm{~h}$ under vacuum. Under an argon flow, the Ge precursor solution was injected into the flask. Then the flask was heated to $280{ }^{\circ} \mathrm{C}\left(10^{\circ} \mathrm{C} / \mathrm{min}\right)$ and held for $5 \mathrm{~min}$, and a red-brown colloidal solution was obtained. The other procedures were similar to that for Ag nanoparticles.

Synthesis of $\mathbf{P b}$ nanoparticles. In the synthesis of $34.4 \mathrm{~nm} \mathrm{~Pb}$ nanoparticles, $14 \mathrm{~mL}$ of OAm and $3.5 \mathrm{~mL}$ of ODE, and $47 \mathrm{mg}$ of $\mathrm{PbBr}_{2}$ were added into a three-neck round-bottom flask equipped with a condenser and degassed at $120{ }^{\circ} \mathrm{C}$ under vacuum. After the flask was cooled to room temperature, $50 \mathrm{mg}$ of $\mathrm{W}(\mathrm{CO})_{6}$ and $1 \mathrm{~mL}$ of HMDS were added. The mixture was then heated to $220^{\circ} \mathrm{C}$ and kept for 40 min with vigorous stirring under an argon stream. The resultant products were cleaned and stored, similar to that for $\mathrm{Ag}$ nanoparticles. For the synthesis of $16.6 \mathrm{~nm} \mathrm{~Pb}$ nanoparticles, a hot injection method was necessary. $14 \mathrm{~mL}$ of OAm and $3.5 \mathrm{~mL}$ of ODE, $1 \mathrm{~mL}$ of HMDS, and $47 \mathrm{mg}$ of $\mathrm{PbBr}_{2}$ were added into a three-neck round-bottom flask and degassed at $120{ }^{\circ} \mathrm{C}$ under vacuum. When the temperature was raised to $220^{\circ} \mathrm{C}, 50 \mathrm{mg}$ of $\mathrm{W}(\mathrm{CO})_{6}$ was quickly added into the reaction system. After $40 \mathrm{~min}$, the solution was quickly cooled down. The rest processes are the same as that of Ag nanoparticles.

Synthesis of Ag-Pd nanoparticles. In a typical synthesis of $\mathrm{Ag}_{87} \mathrm{Pd}_{13}$ nanoparticles, $50 \mathrm{mg}$ of $\mathrm{W}(\mathrm{CO})_{6}, 40 \mathrm{mg}$ of $\mathrm{AgNO}_{3}$, and $10 \mathrm{mg}$ of $\mathrm{Pd}(\mathrm{acac})_{2}$ were mixed with $10 \mathrm{~mL}$ of OAm under argon flow in a three-neck round-bottom flask with vigorous stirring. Then, the solution temperature was raised to $240{ }^{\circ} \mathrm{C}$ and kept for $60 \mathrm{~min}$. At last, the solution was quickly cooled down, purified using similar methods to $\mathrm{Ag}$ nanoparticles, and finally dispersed in hexane. For the synthesis of $\mathrm{Ag}_{78} \mathrm{Pd}_{22}$ 
nanoparticles, $20 \mathrm{mg}$ of $\mathrm{Pd}(\mathrm{acac})_{2}$ was used and other conditions were same as that of $\mathrm{Ag}_{87} \mathrm{Pd}_{13}$ nanoparticles.

Synthesis of Pd-Ni nanoparticles. The Ni-(II)-OAm solution was prepared first: 71 $\mathrm{mg}$ of $\mathrm{Ni}\left(\mathrm{CH}_{3} \mathrm{COO}\right)_{2} \bullet 4 \mathrm{H}_{2} \mathrm{O}$ and $8 \mathrm{~mL}$ of OAm were placed into a $100 \mathrm{~mL}$ vial, which was sealed and vacuumed at $150{ }^{\circ} \mathrm{C}$ for about $30 \mathrm{~min}$. In a typical synthesis of $\mathrm{Pd}_{85} \mathrm{Ni}_{15}$ nanoparticles, $50 \mathrm{mg}$ of $\mathrm{W}(\mathrm{CO})_{6}, 32.5 \mathrm{mg}$ of $\mathrm{Pd}(\mathrm{acac})_{2}$ and $2 \mathrm{~mL}$ of Ni-(II)-OAm solution were mixed with $6 \mathrm{~mL}$ of OAm and $2 \mathrm{~mL}$ of TOP in a three-neck round-bottom flask with vigorous stirring. Then, the solution temperature was raised to $260{ }^{\circ} \mathrm{C}$ and kept for $40 \mathrm{~min}$. At last, the solution was quickly cooled down, purified using similar methods to Ag nanoparticles, and finally dispersed in hexane. For the synthesis of $\mathrm{Pd}_{53} \mathrm{Ni}_{47}$ nanoparticles, $4 \mathrm{~mL}$ of $\mathrm{Ni}$-(II)-OAm solution and $4 \mathrm{~mL}$ of OAm were used and other conditions were same as that of $\mathrm{Pd}_{85} \mathrm{Ni}_{15}$ nanoparticles.

Ligand exchange. To remove $\mathrm{W}$ species absorbed on the surface of metal nanoparticles, ligand exchange processes with 1-dodecanethiol or $\left(\mathrm{NH}_{4}\right)_{2} \mathrm{~S}$ were performed. (i) For metal nanoparticles ( $\mathrm{Au}, \mathrm{Ag}, \mathrm{Ni}$, and $\mathrm{In}$ ), a ligand exchange with 1-dodecanethiol was carried out. Typically, these nanoparticles were first dispersed in $10 \mathrm{~mL}$ of hexane, and then $2 \mathrm{~mL}$ of 1-dodecanethiol was added. After stirring for 5 minutes, the product was purified several times by adding $10 \mathrm{~mL}$ of ethanol. (ii) For Fe and Ge nanoparticles, a ligand exchange with $\left(\mathrm{NH}_{4}\right)_{2} \mathrm{~S}$ was carried out. Typically, Fe or Ge nanoparticles were dissolved into $1 \mathrm{~mL}$ of chloroform, and $10 \mathrm{~mL}$ of formamide with $1 \mathrm{~mL}$ of $\left(\mathrm{NH}_{4}\right)_{2} \mathrm{~S}$ solution were added. After stirring for $2 \mathrm{~h}$, the product was purified several times by adding $10 \mathrm{~mL}$ of formamide. (iii) For other metal nanoparticles $(\mathrm{Pd}, \mathrm{Co}, \mathrm{Cu}$, and $\mathrm{Pb})$, several times purification process using hexane and ethanol was enough to remove the residual $\mathrm{W}$ species. After repeating these processes several times, the final products were used for further ICP-MS characterizations.

Characterizations. X-ray diffraction (XRD) patterns were recorded on an X-ray diffractometer (Rigaku SmartLab) with $\mathrm{Cu} \mathrm{K \alpha}$ radiation $(\lambda=0.15418 \mathrm{~nm})$ at a voltage of $45 \mathrm{kV}$ and a current of $200 \mathrm{~mA}$. Transmission electron microscope (TEM) images and elemental mapping were obtained using FEI Tecnai F30 electron microscope $(300 \mathrm{kV})$. TEM samples were prepared by placing a drop of the nanoparticle colloidal solution onto a carbon-coated $\mathrm{Cu}$ grid under ambient conditions. The elements on the surface of these nanoparticles were determined by X-ray photoelectron spectroscopy (XPS, PHI 5000 VersaProbe II). The metal compositions after ligand removal were measured using inductively coupled plasma mass spectrometry (ICP-MS, Agilent 7700x). 


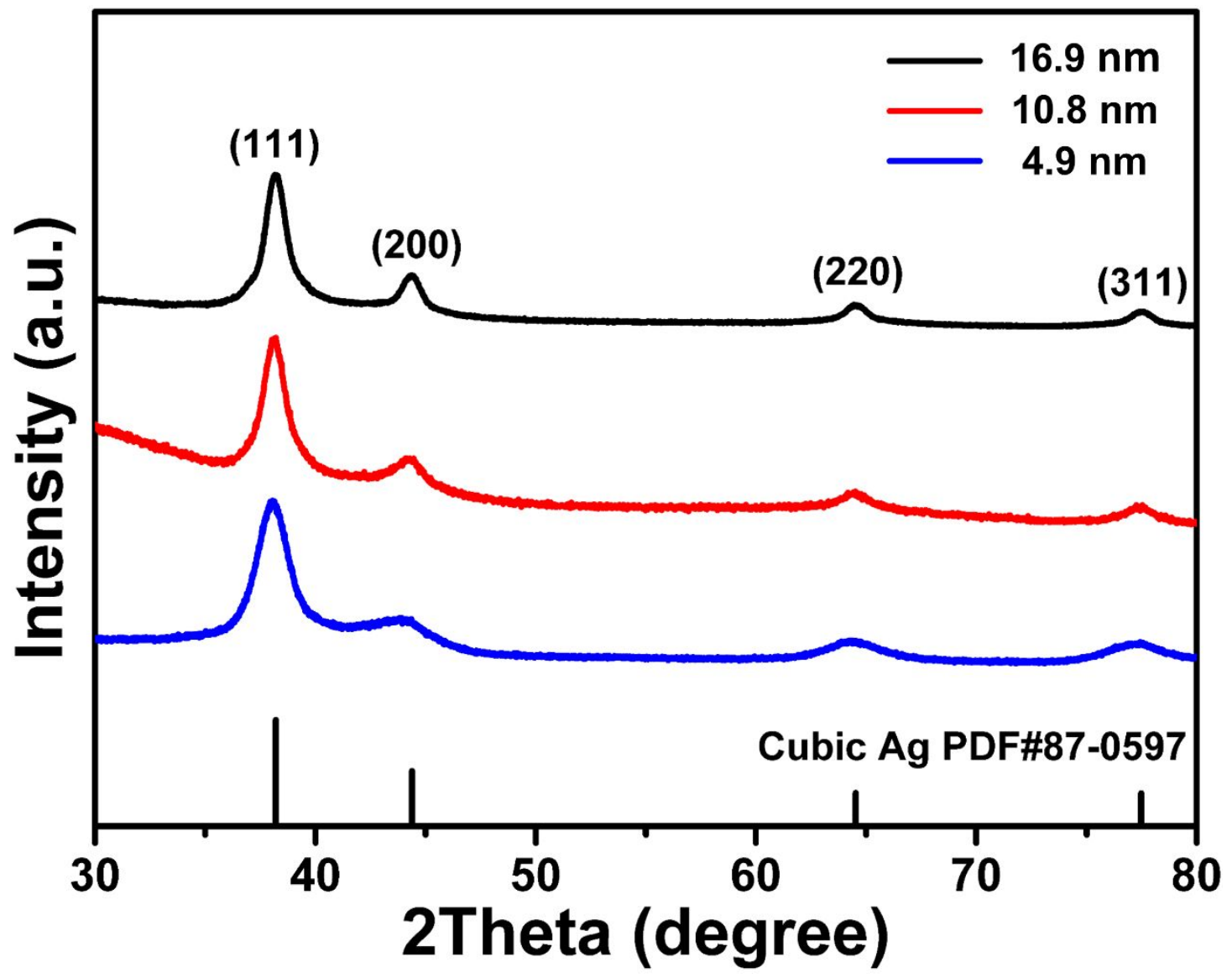

Figure S1. The XRD patterns of the as-prepared Ag nanoparticles in different sizes. 

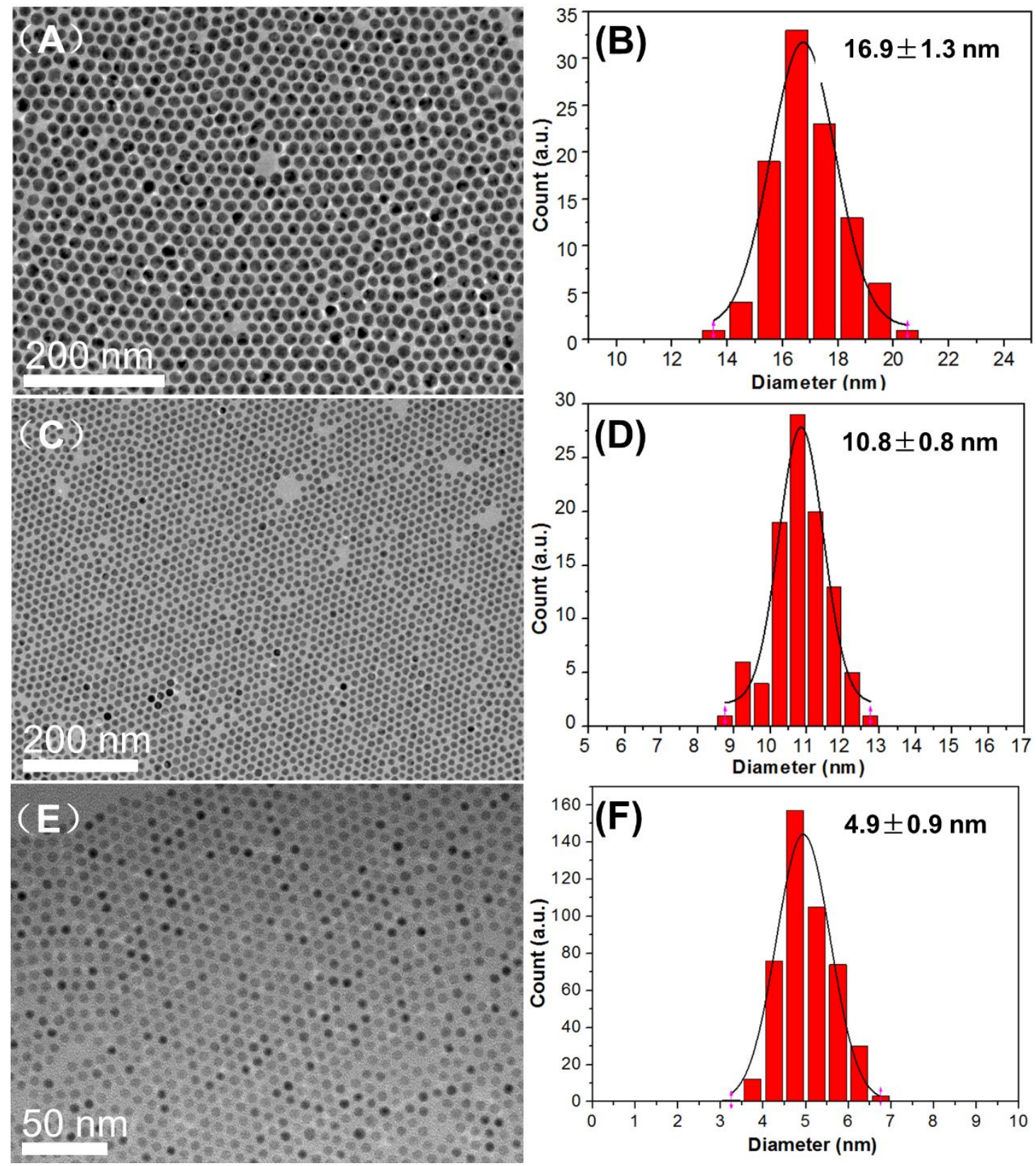

Figure S2. TEM images and size-distribution histograms of Ag nanoparticles prepared (A, B) with TOP $(1 \mathrm{~mL}),(\mathrm{C}, \mathrm{D})$ without TOP or DDT, and $(\mathrm{E}, \mathrm{F})$ with DDT $(0.1 \mathrm{~mL})$ through $\mathrm{W}(\mathrm{CO})_{6}$-assisted reduction. 

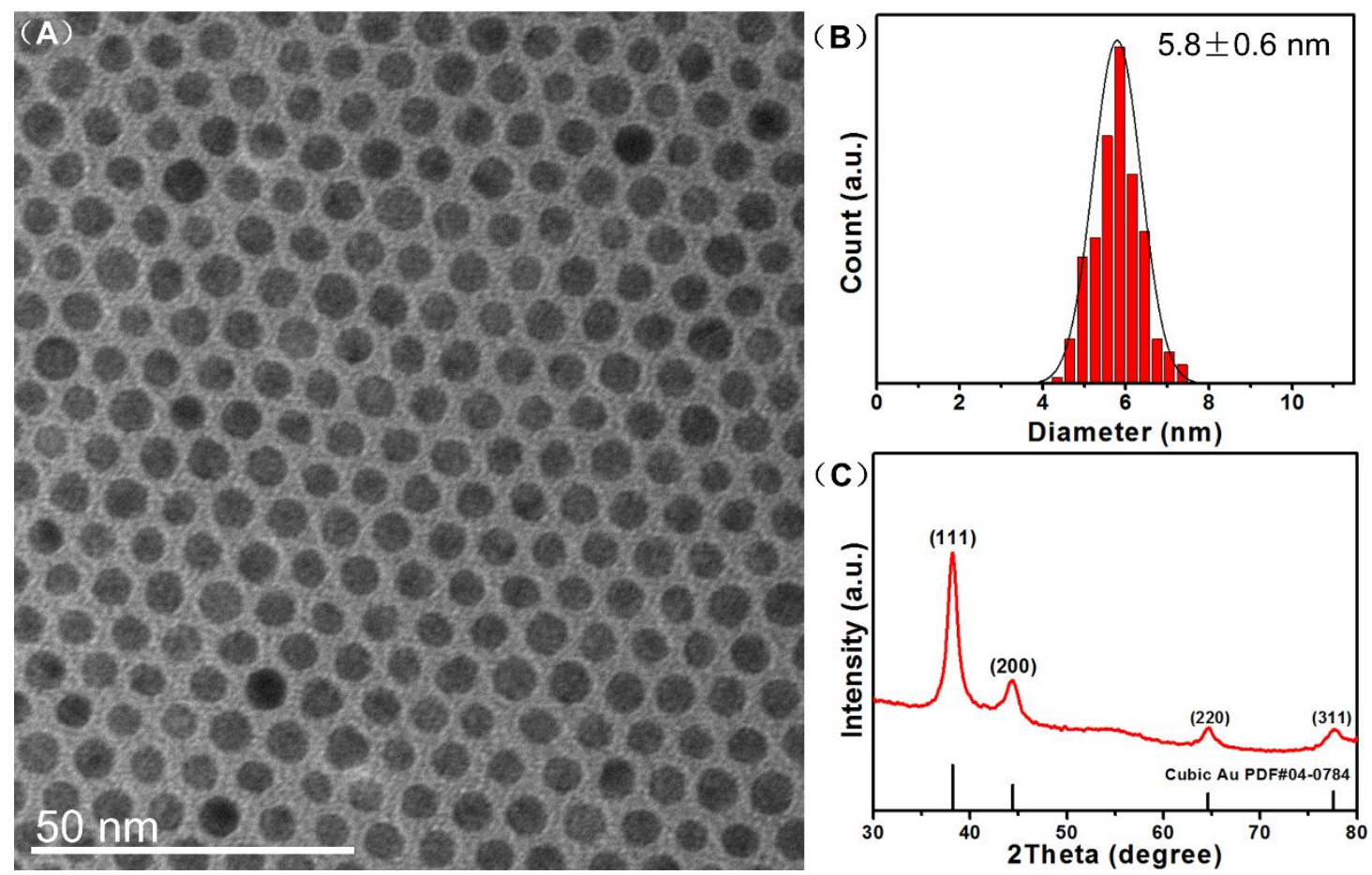

Figure S3. TEM image (A), size-distribution histogram (B), and XRD pattern (C) of $\mathrm{Au}$ nanoparticles prepared through $\mathrm{W}(\mathrm{CO})_{6}$-assisted reduction. 


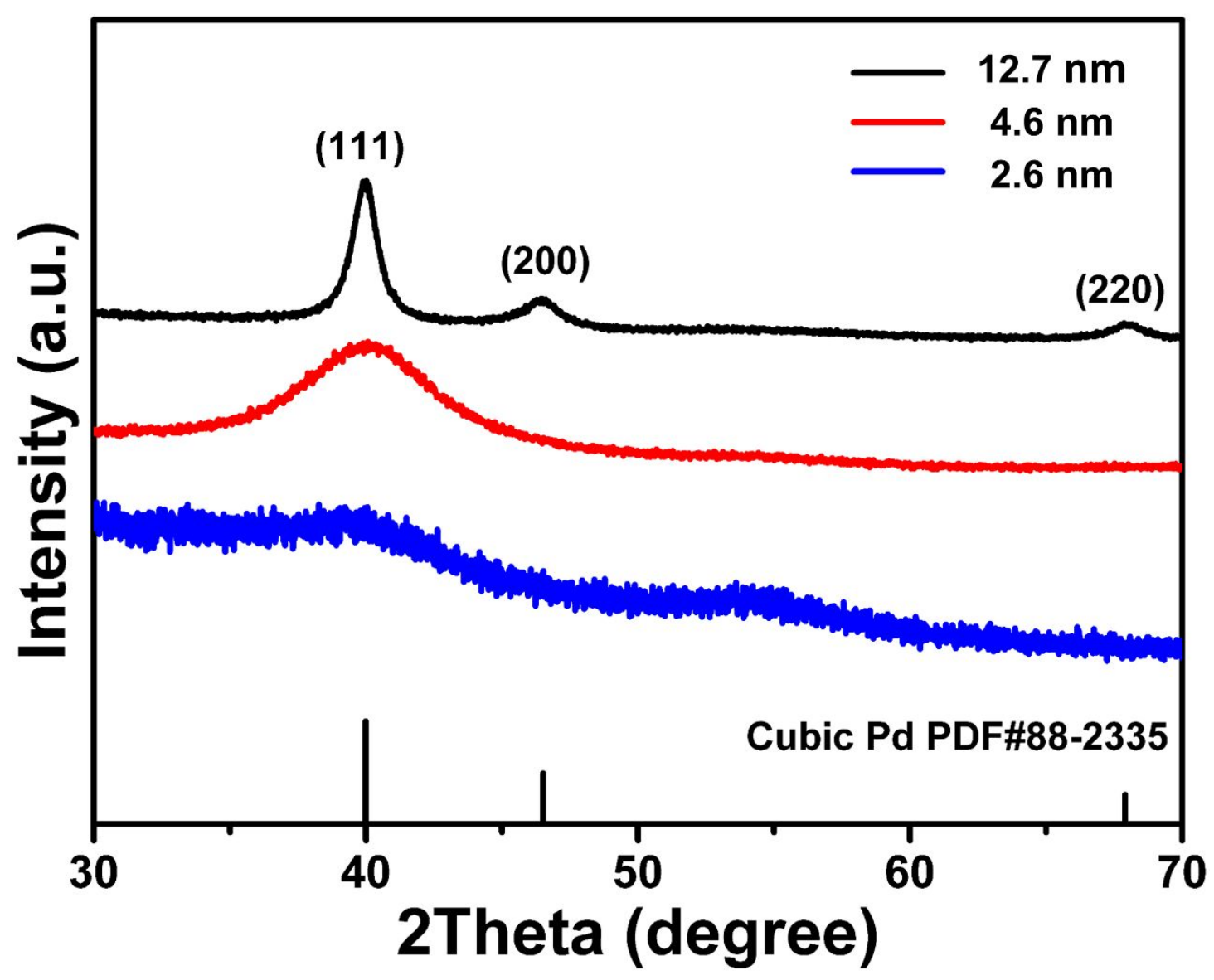

Figure S4. XRD patterns of the as-prepared Pd nanoparticles in different sizes. 

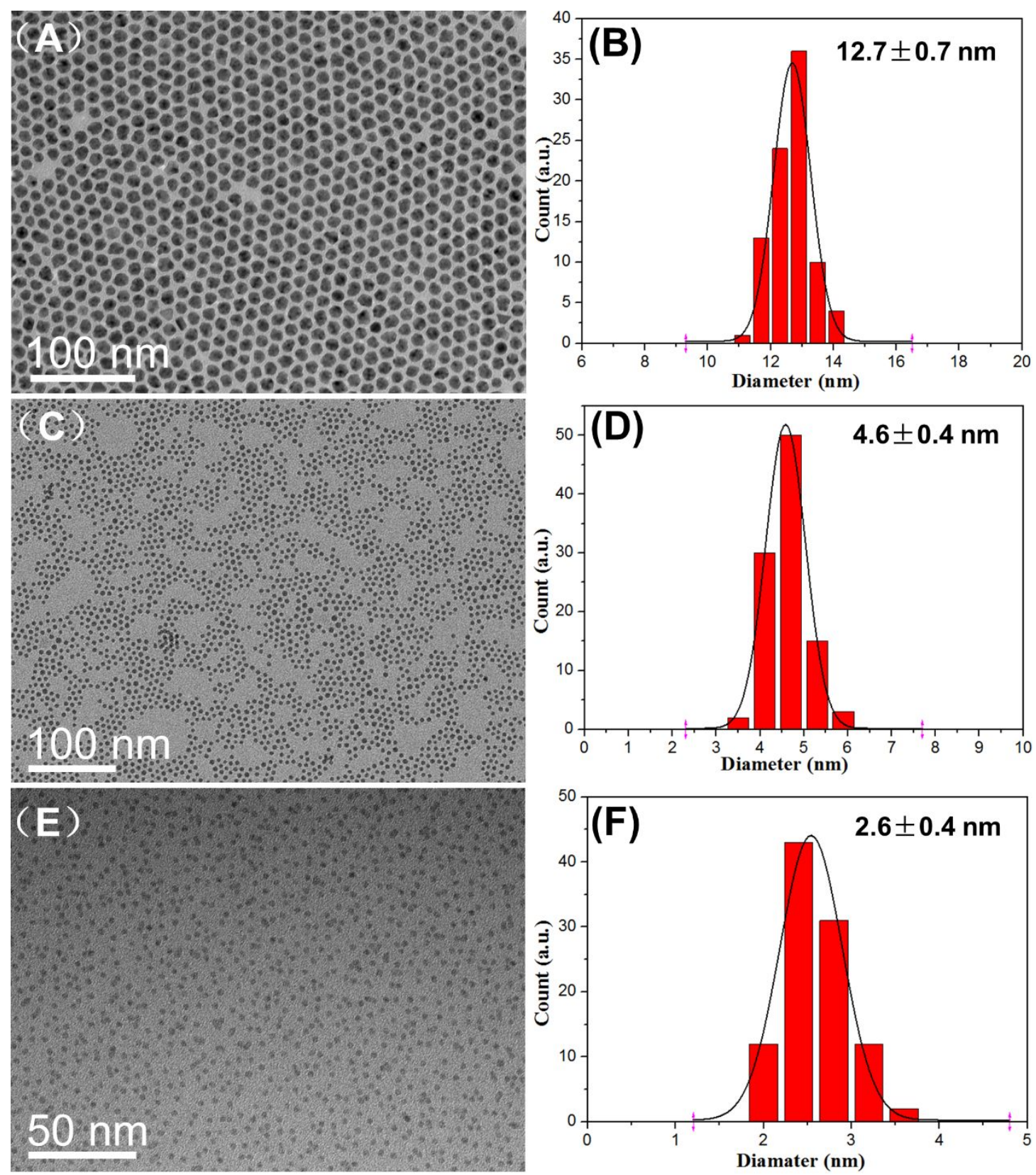

Figure S5. TEM images and size-distribution histograms of Pd nanoparticles prepared (A, B) without TOP, (C, D) with TOP $(0.5 \mathrm{~mL})$, and $(\mathrm{E}, \mathrm{F})$ with TOP $(0.1 \mathrm{~mL})$ through $\mathrm{W}(\mathrm{CO})_{6}$-assisted reduction. 

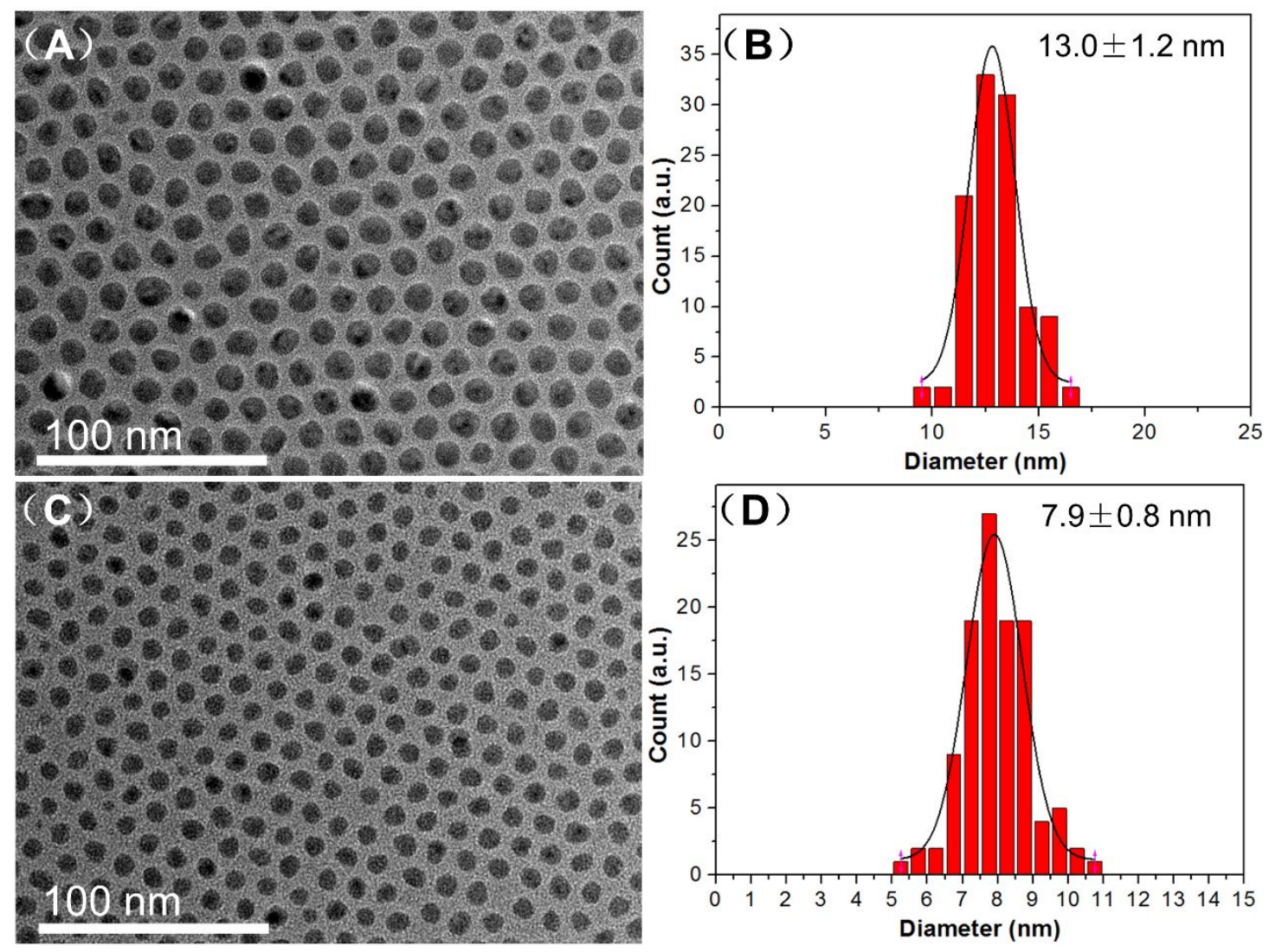

Figure S6. TEM images and size-distribution histograms of Ni nanoparticles prepared (A, B) with TOP $(2 \mathrm{~mL})$ and $(\mathrm{C}, \mathrm{D})$ with TOP $(3 \mathrm{~mL})$ through $\mathrm{W}(\mathrm{CO})_{6}$-assisted reduction. 


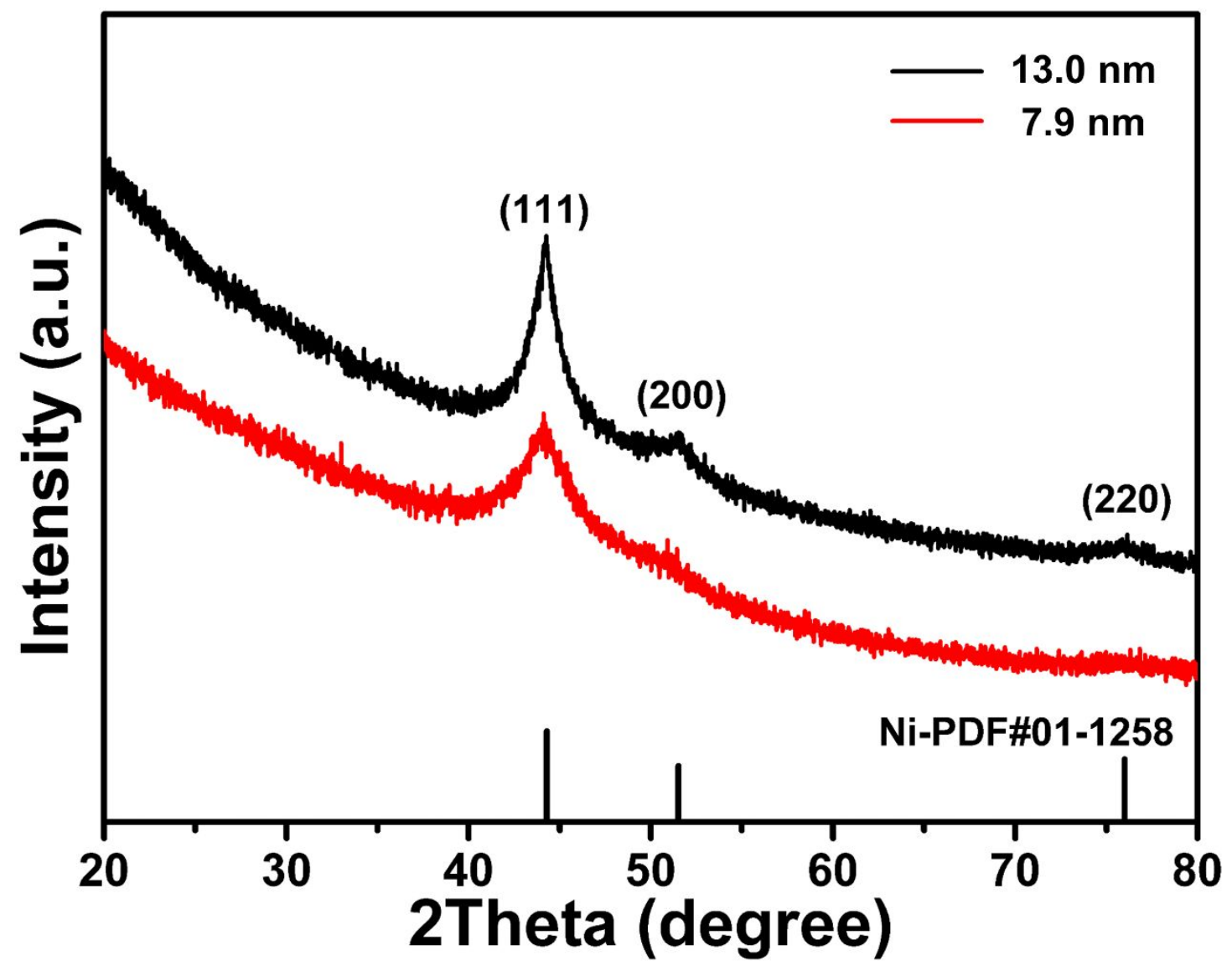

Figure S7. XRD patterns of the as-prepared Ni nanoparticles in different sizes. 

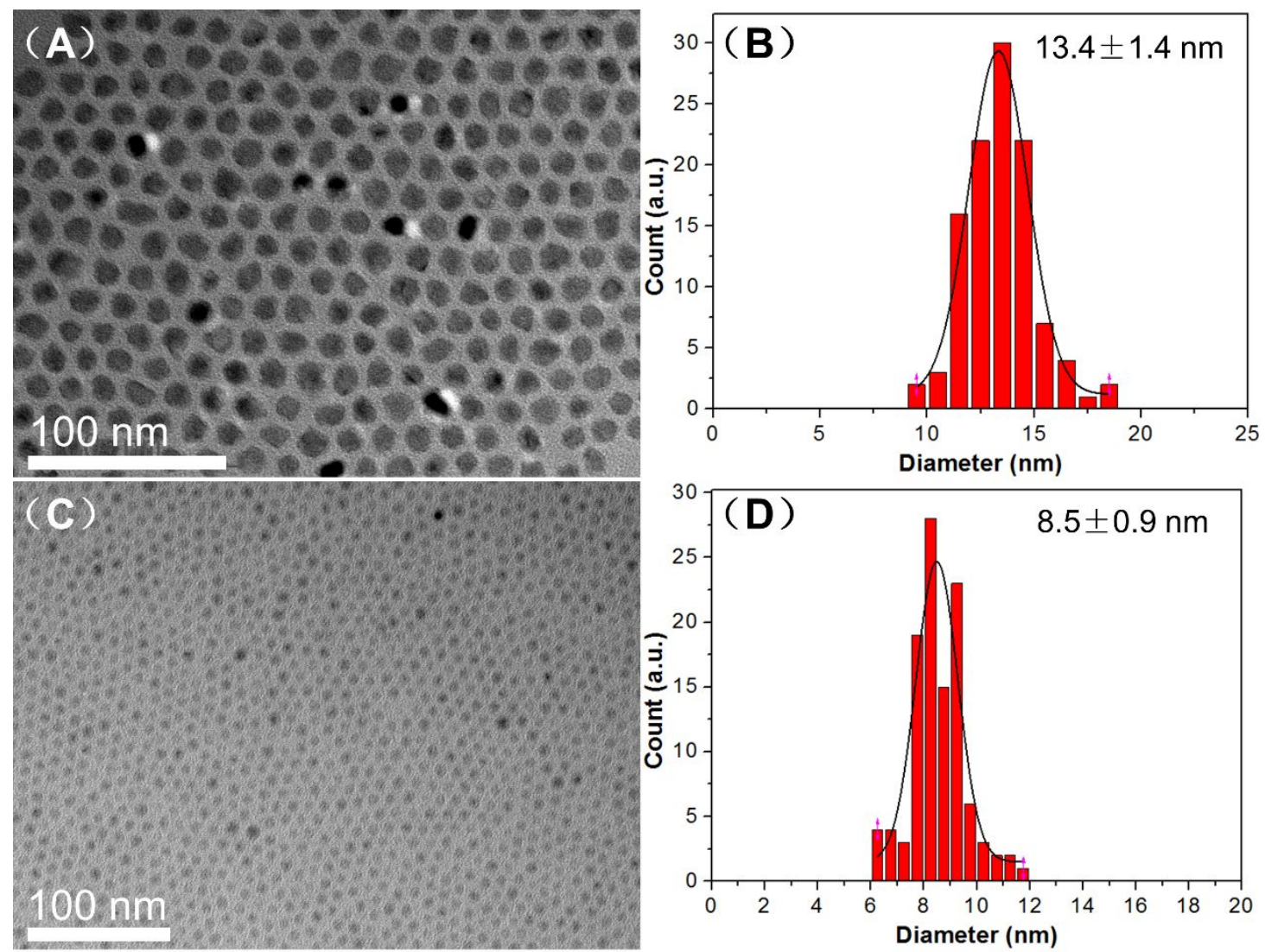

Figure S8. TEM images and size-distribution histograms of Co nanoparticles prepared (A, B) with TOP $(1 \mathrm{~mL})$ and $\mathrm{OA}(0.1 \mathrm{~mL})$ at $260^{\circ} \mathrm{C}$ for $20 \mathrm{~min}$ and $(\mathrm{C}, \mathrm{D})$ with TOP $(1 \mathrm{~mL})$ at $240^{\circ} \mathrm{C}$ for 10 min through $\mathrm{W}(\mathrm{CO})_{6}$-assisted reduction. 


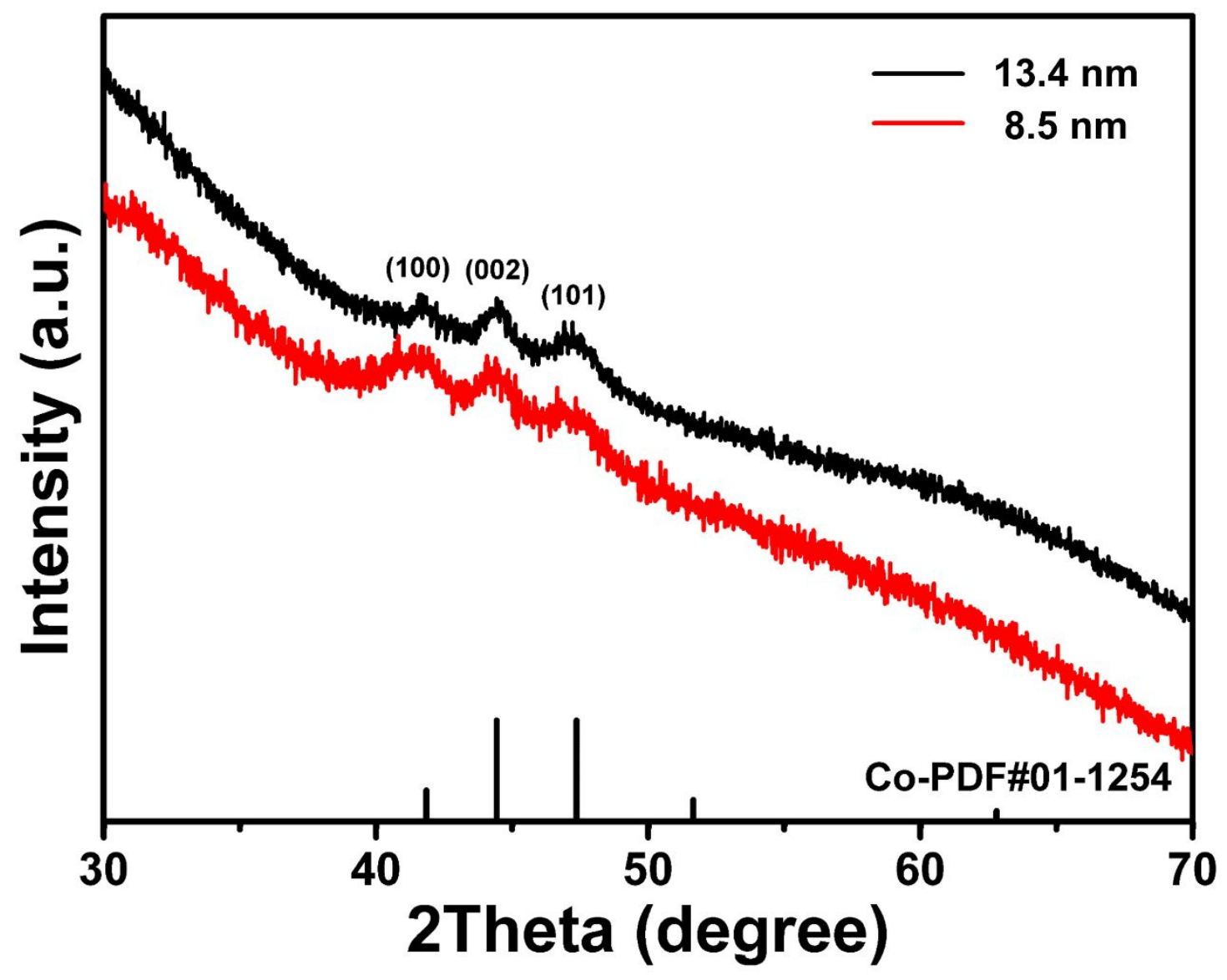

Figure S9. XRD patterns of the as-prepared Co nanoparticles in different sizes. 

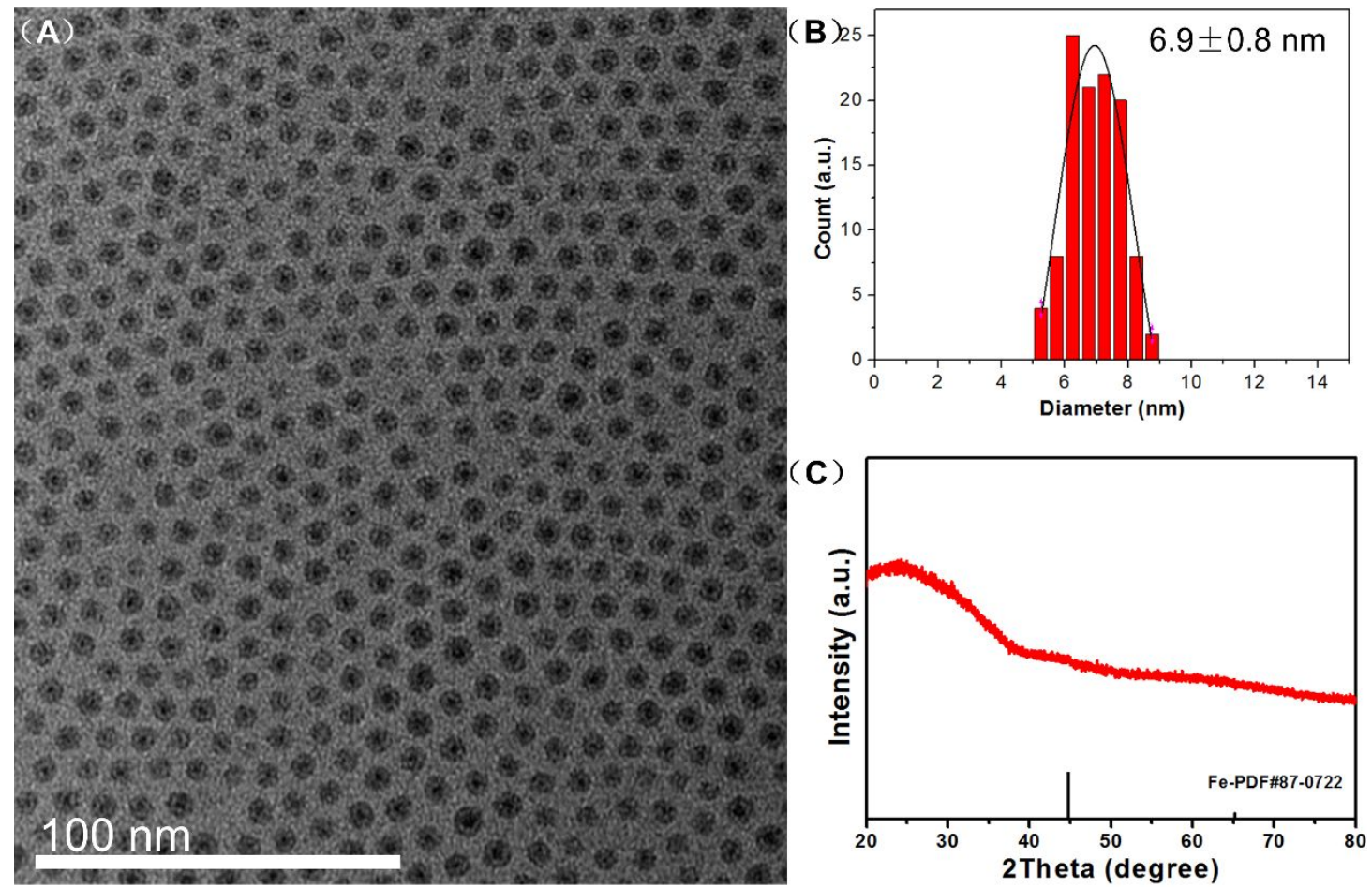

Figure S10. TEM image (A), size-distribution histogram (B), and XRD pattern (C) of Fe nanoparticles prepared at $260^{\circ} \mathrm{C}$ for $15 \mathrm{~min}$ through $\mathrm{W}(\mathrm{CO})_{6}$-assisted reduction. 

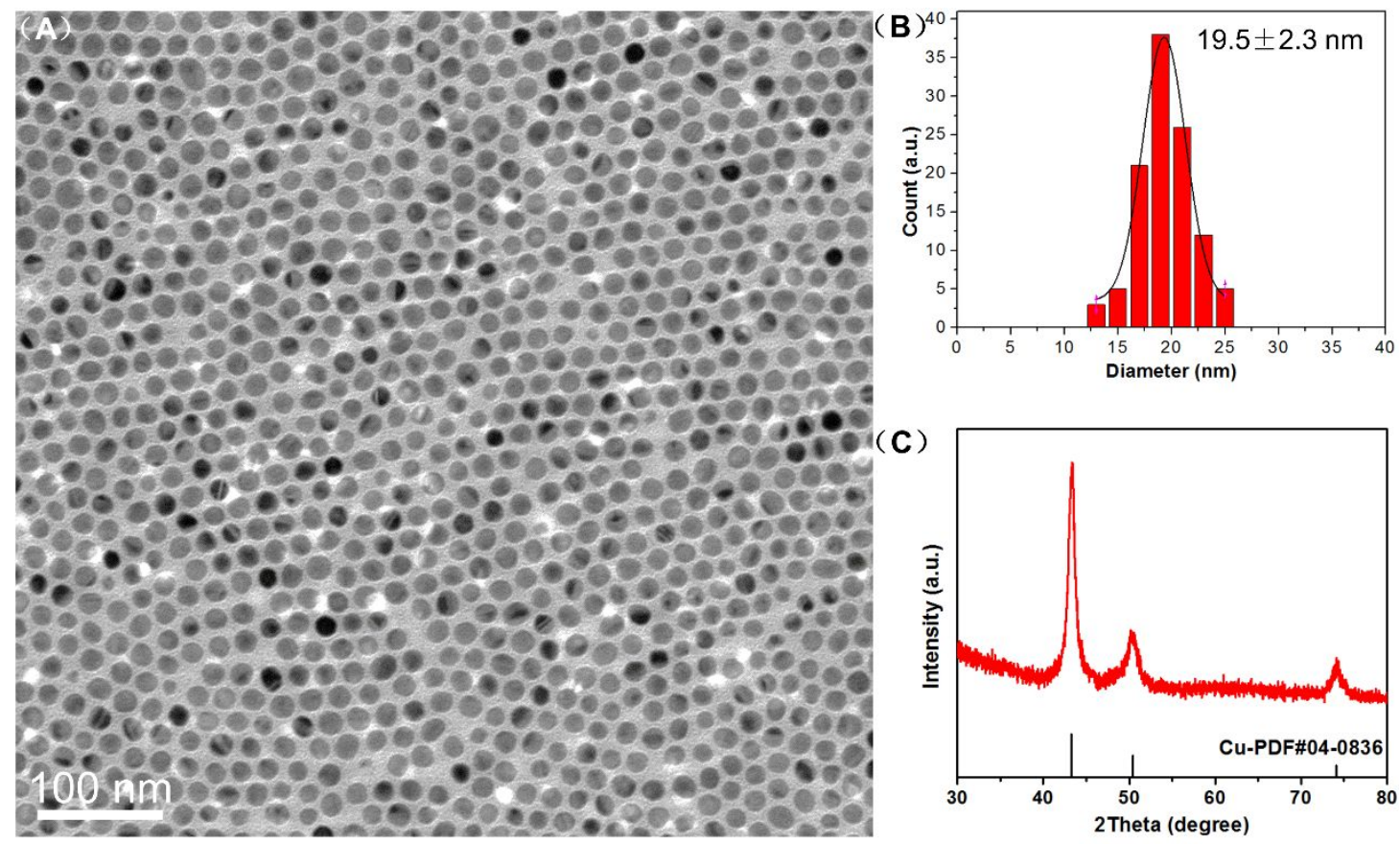

Figure S11. TEM image (A), size-distribution histogram (B), and XRD pattern (C) of $\mathrm{Cu}$ nanoparticles prepared at $250^{\circ} \mathrm{C}$ for 20 min through $\mathrm{W}(\mathrm{CO})_{6}$-assisted reduction. 

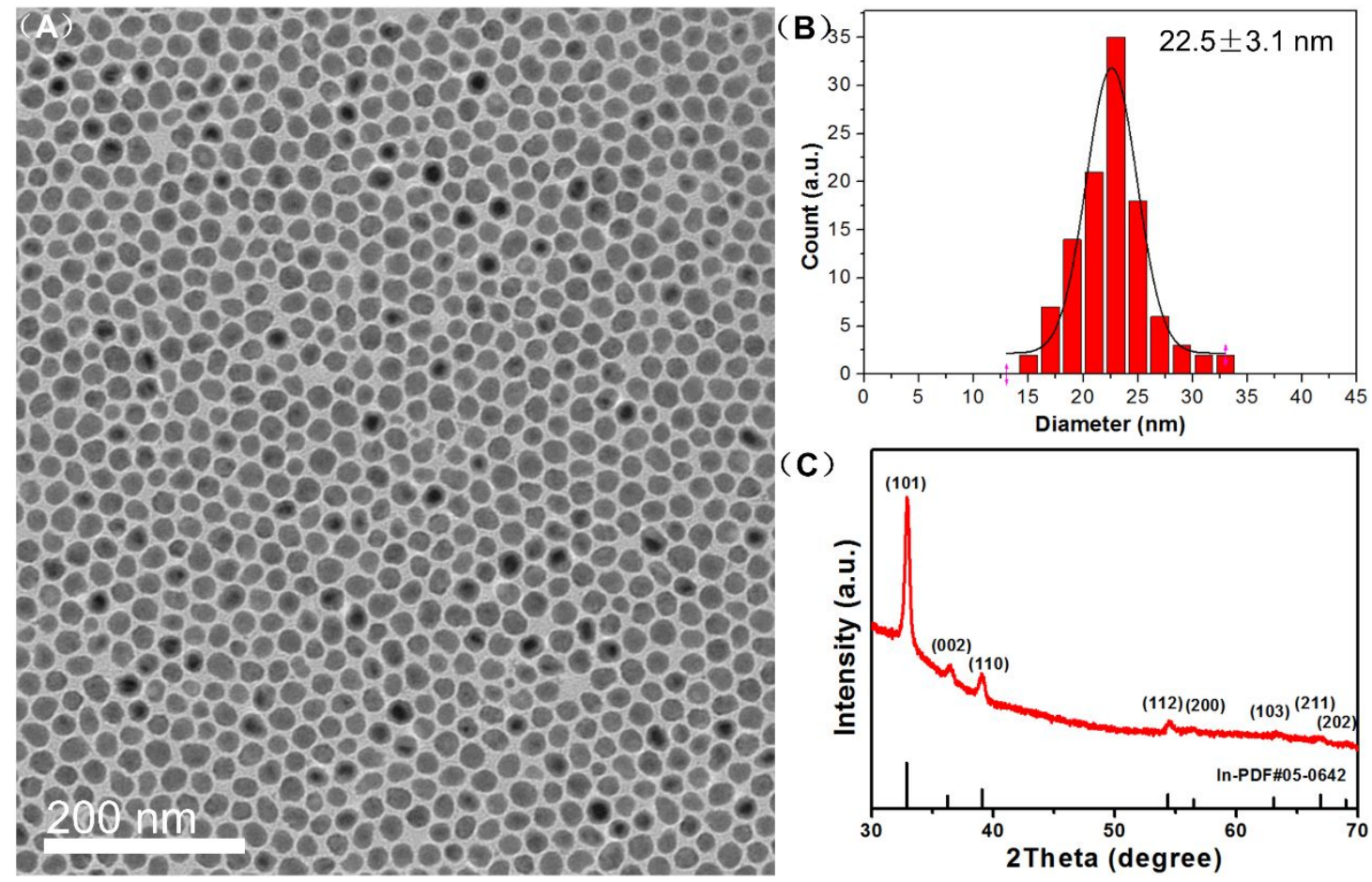

Figure S12. TEM image (A), size-distribution histogram (B), and XRD pattern (C) of In nanoparticles prepared at $280^{\circ} \mathrm{C}$ for 15 min through $\mathrm{W}(\mathrm{CO})_{6}$-assisted reduction. 


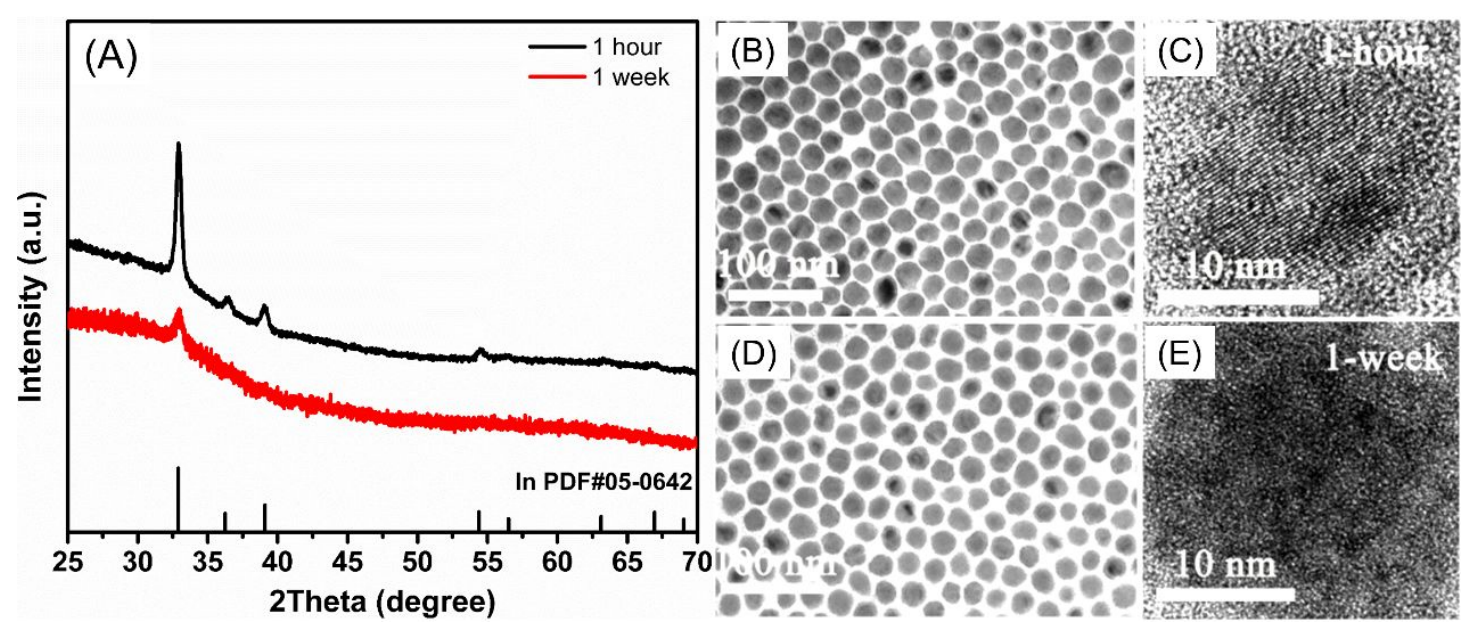

Figure S13. XRD patterns (A) and TEM/HRTEM images of the as-prepared In nanoparticles exposed to air for one hour (B and $C$ ) and for one week (D and E). As seen from the weakened peaks in the XRD pattern (A, red line) and obscure lattice fringes in TEM image (E) of In nanoparticles at different periods, these In nanoparticles gradually transformed into amorphous upon prolonged exposure to air. 

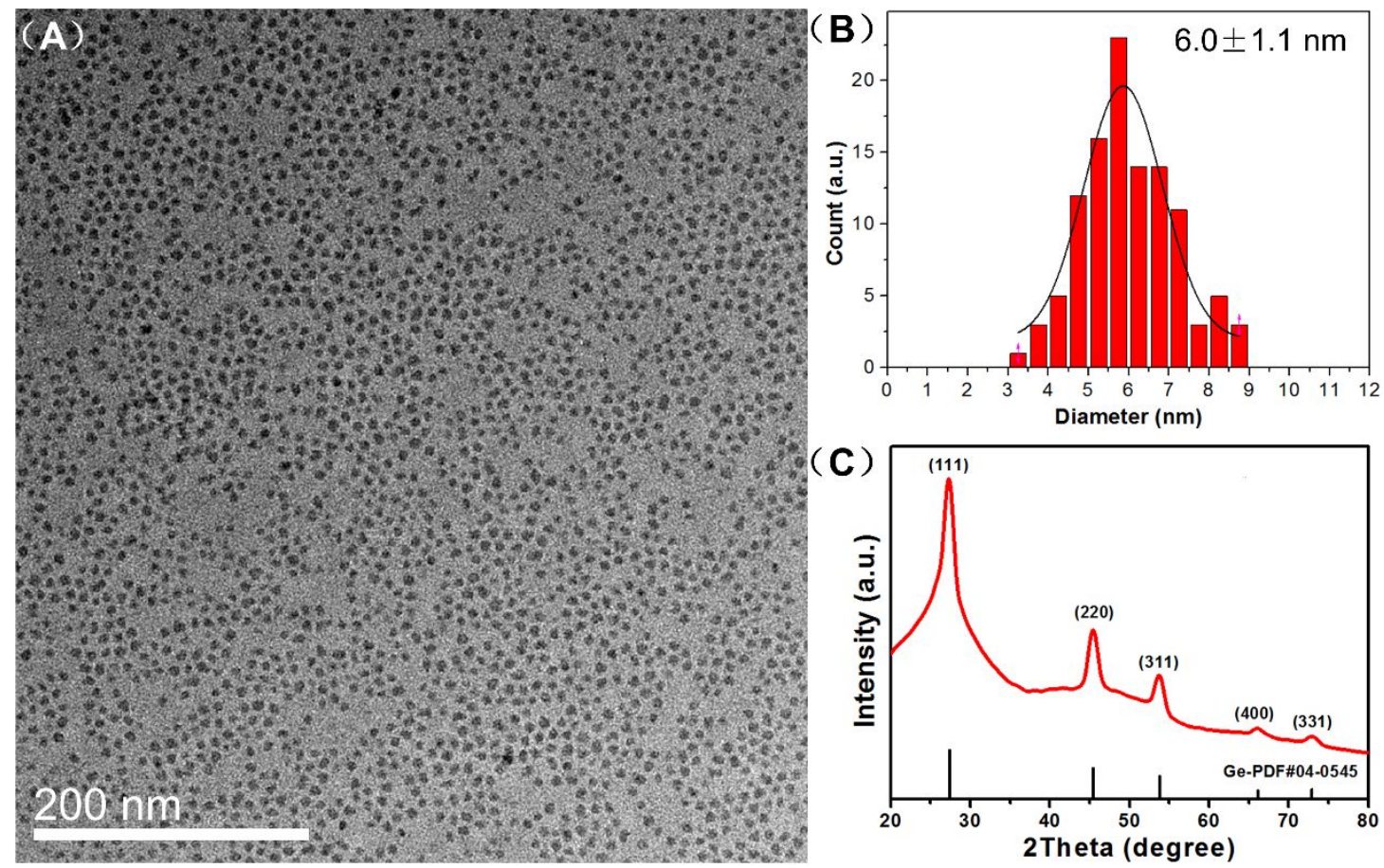

Figure S14. TEM image (A), size-distribution histogram (B), and XRD pattern (C) of Ge nanoparticles prepared at $280^{\circ} \mathrm{C}$ for 5 min through $\mathrm{W}(\mathrm{CO})_{6}$-assisted reduction. 

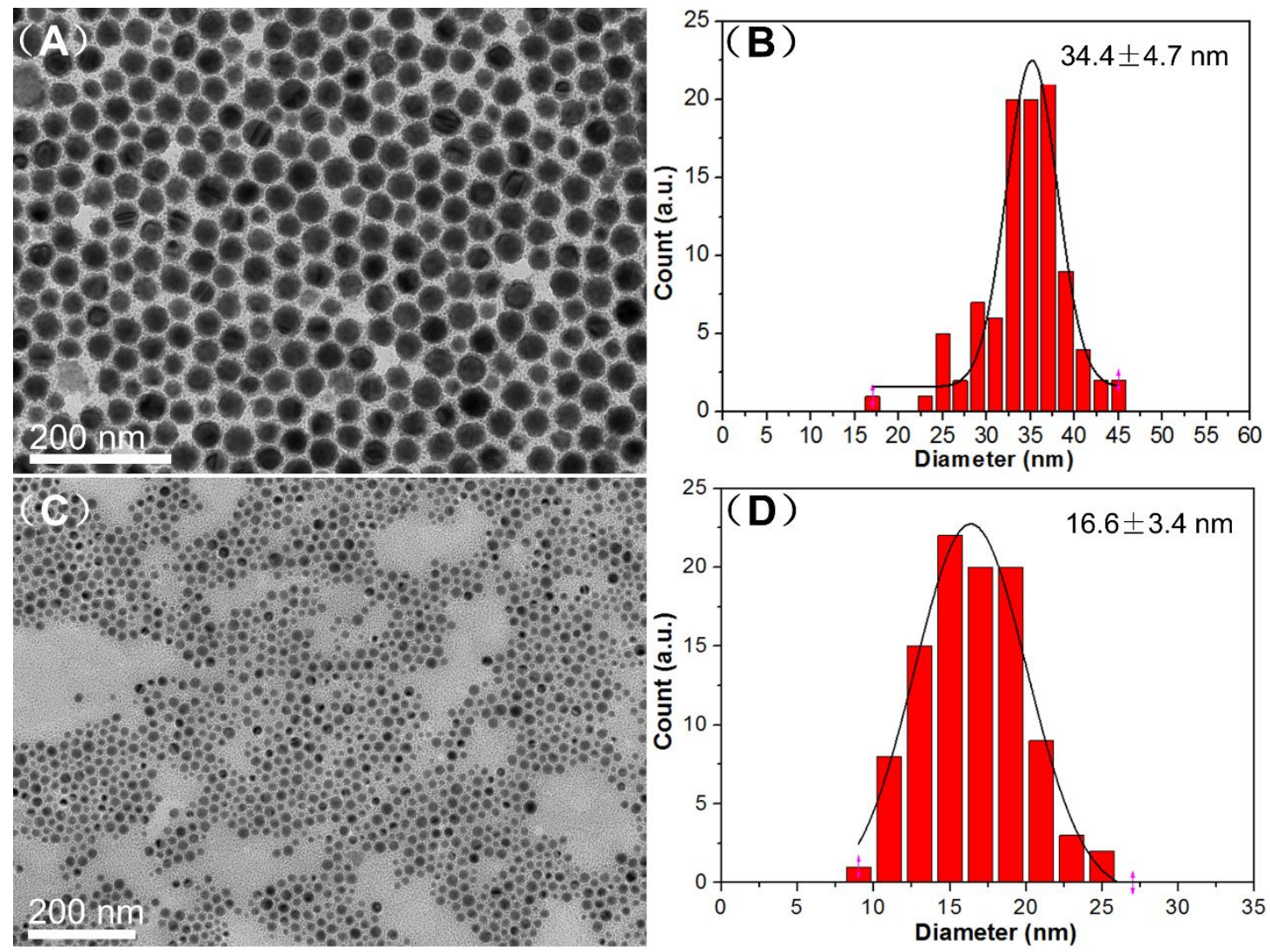

Figure S15. TEM images and size-distribution histograms of $\mathrm{Pb}$ nanoparticles prepared by using (A, B) heat-up method and (C, D) hot-injection method at $220^{\circ} \mathrm{C}$ for $40 \mathrm{~min}$ through $\mathrm{W}(\mathrm{CO})_{6}$-assisted reduction. 


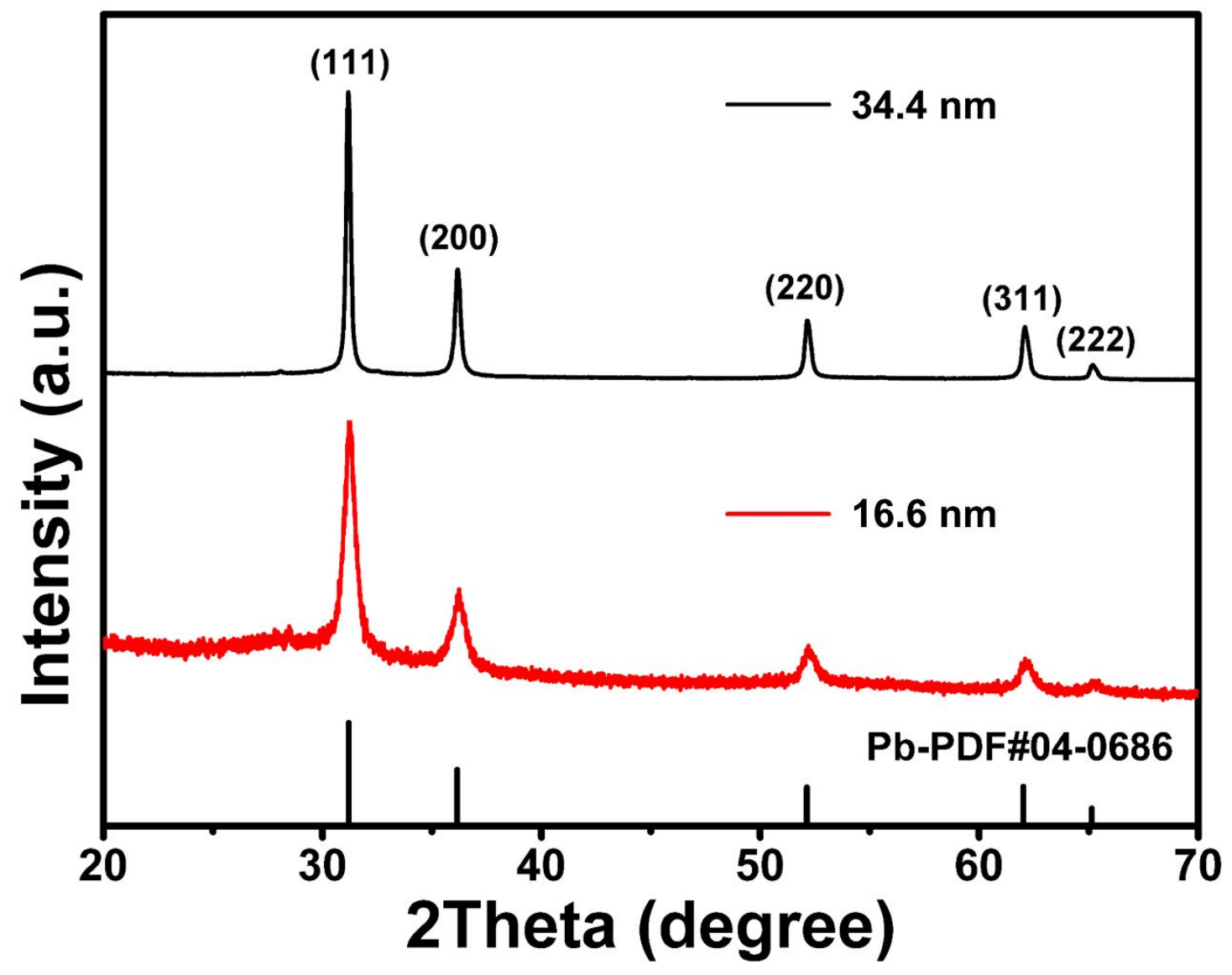

Figure S16. XRD patterns of the as-prepared $\mathrm{Pb}$ nanoparticles in different sizes. 
Table S1. Experimental details for the controlled synthesis of uniform metal nanoparticles.

\begin{tabular}{|c|c|c|c|c|}
\hline Metal & Temperature/duration & Chemical agents & Method & Size/shape \\
\hline \multirow{3}{*}{ Ag } & $240^{\circ} \mathrm{C} / 1 \mathrm{~h}$ & $\mathrm{~W}(\mathrm{CO})_{6}, \mathrm{AgNO}_{3}, \mathrm{OAm}, \mathrm{ODE}, \mathrm{TOP}$ & heat-up & $17 \mathrm{~nm} / \mathrm{spheres}$ \\
\hline & $240^{\circ} \mathrm{C} / 1 \mathrm{~h}$ & $\mathrm{~W}(\mathrm{CO})_{6}, \mathrm{AgNO}_{3}, \mathrm{OAm}, \mathrm{ODE}$ & heat-up & $11 \mathrm{~nm} / \mathrm{spheres}$ \\
\hline & $240^{\circ} \mathrm{C} / 1 \mathrm{~h}$ & $\mathrm{~W}(\mathrm{CO})_{6}, \mathrm{AgNO}_{3}, \mathrm{OAm}, \mathrm{ODE}, \mathrm{DDT}$ & heat-up & $5 \mathrm{~nm} / \mathrm{spheres}$ \\
\hline Au & $130^{\circ} \mathrm{C} / 30 \mathrm{~min}$ & $\mathrm{~W}(\mathrm{CO})_{6}, \mathrm{HAuCl}_{4} \cdot 3 \mathrm{H}_{2} \mathrm{O}, \mathrm{OAm}, \mathrm{OA}$ & hot-injection & $6 \mathrm{~nm} / \mathrm{spheres}$ \\
\hline \multirow{3}{*}{ Pd } & $180^{\circ} \mathrm{C} / 30 \mathrm{~min}$ & $\mathrm{~W}(\mathrm{CO})_{6}, \mathrm{Pd}(\mathrm{acac})_{2}, \mathrm{OAm}, \mathrm{ODE}$ & heat-up & $12.5 \mathrm{~nm} / \mathrm{spheres}$ \\
\hline & $240^{\circ} \mathrm{C} / 30 \mathrm{~min}$ & $\mathrm{~W}(\mathrm{CO})_{6}, \mathrm{Pd}(\mathrm{acac})_{2}, \mathrm{OAm}, \mathrm{ODE}, \mathrm{TOP}$ & heat-up & $4.5 \mathrm{~nm} / \mathrm{spheres}$ \\
\hline & $240^{\circ} \mathrm{C} / 30 \mathrm{~min}$ & $\mathrm{~W}(\mathrm{CO})_{6}, \mathrm{Pd}(\mathrm{acac})_{2}, \mathrm{OAm}, \mathrm{ODE}, \mathrm{TOP}$ & heat-up & $2.5 \mathrm{~nm} / \mathrm{spheres}$ \\
\hline $\mathbf{F e}$ & $260^{\circ} \mathrm{C} / 15 \mathrm{~min}$ & $\mathrm{~W}(\mathrm{CO})_{6}, \mathrm{FeCl}_{2} \cdot 4 \mathrm{H}_{2} \mathrm{O}, \mathrm{OAm}, \mathrm{HMDS}$ & heat-up & $7 \mathrm{~nm} / \mathrm{spheres}$ \\
\hline \multirow{2}{*}{ Co } & $260^{\circ} \mathrm{C} / 20 \mathrm{~min}$ & $\mathrm{~W}(\mathrm{CO})_{6}, \mathrm{Co}\left(\mathrm{CH}_{3} \mathrm{COO}\right)_{2} \bullet 4 \mathrm{H}_{2} \mathrm{O}, \mathrm{OAm}, \mathrm{OA}$ & heat-up & $13 \mathrm{~nm} / \mathrm{spheres}$ \\
\hline & $240^{\circ} \mathrm{C} / 10 \mathrm{~min}$ & $\mathrm{~W}(\mathrm{CO})_{6}, \mathrm{Co}\left(\mathrm{CH}_{3} \mathrm{COO}\right)_{2} \bullet 4 \mathrm{H}_{2} \mathrm{O}, \mathrm{OAm}, \mathrm{TOP}$ & heat-up & $8.5 \mathrm{~nm} / \mathrm{spheres}$ \\
\hline \multirow{2}{*}{ Ni } & $220^{\circ} \mathrm{C} / 40 \mathrm{~min}$ & $\mathrm{~W}(\mathrm{CO})_{6}, \mathrm{Ni}\left(\mathrm{CH}_{3} \mathrm{COO}\right)_{2} \bullet 4 \mathrm{H}_{2} \mathrm{O}, \mathrm{OAm}, \mathrm{ODE}, \mathrm{TOP}$ & heat-up & $13 \mathrm{~nm} / \mathrm{spheres}$ \\
\hline & $220^{\circ} \mathrm{C} / 40 \mathrm{~min}$ & $\mathrm{~W}(\mathrm{CO})_{6}, \mathrm{Ni}\left(\mathrm{CH}_{3} \mathrm{COO}\right)_{2} \bullet 4 \mathrm{H}_{2} \mathrm{O}, \mathrm{OAm}$, ODE, TOP & heat-up & $8 \mathrm{~nm} / \mathrm{spheres}$ \\
\hline $\mathrm{Cu}$ & $250^{\circ} \mathrm{C} / 30 \mathrm{~min}$ & $\mathrm{~W}(\mathrm{CO})_{6}, \mathrm{Cu}(\mathrm{acac})_{2}, \mathrm{OAm}, \mathrm{ODE}, \mathrm{TOP}$ & hot-injection & $19.5 \mathrm{~nm} / \mathrm{spheres}$ \\
\hline In & $280^{\circ} \mathrm{C} / 15 \mathrm{~min}$ & $\mathrm{~W}(\mathrm{CO})_{6}, \mathrm{In}\left(\mathrm{CH}_{3} \mathrm{COO}\right)_{3}, \mathrm{OAm}, \mathrm{HMDS}$ & heat-up & $22.5 \mathrm{~nm} / \mathrm{spheres}$ \\
\hline Ge & $280^{\circ} \mathrm{C} / 5 \mathrm{~min}$ & $\mathrm{~W}(\mathrm{CO})_{6}, \mathrm{GeI}_{2}, \mathrm{OAm}, \mathrm{HMDS}, \mathrm{TOP}, \mathrm{DDA}$ & heat-up & $6 \mathrm{~nm} / \mathrm{spheres}$ \\
\hline \multirow{2}{*}{$\mathbf{P b}$} & $220^{\circ} \mathrm{C} / 40 \mathrm{~min}$ & $\mathrm{~W}(\mathrm{CO})_{6}, \mathrm{PbBr}_{2}, \mathrm{OAm}, \mathrm{ODE}, \mathrm{HMDS}$ & heat-up & $34.5 \mathrm{~nm} / \mathrm{spheres}$ \\
\hline & $220^{\circ} \mathrm{C} / 40 \mathrm{~min}$ & $\mathrm{~W}(\mathrm{CO})_{6}, \mathrm{PbBr}_{2}, \mathrm{OAm}, \mathrm{ODE}, \mathrm{HMDS}$ & hot-injection & $16.5 \mathrm{~nm} / \mathrm{spheres}$ \\
\hline $\mathbf{A g}_{87} \mathbf{P d}_{13}$ & $240^{\circ} \mathrm{C} / 1 \mathrm{~h}$ & $\mathrm{~W}(\mathrm{CO})_{6}, \mathrm{AgNO}_{3}, \mathrm{Pd}(\mathrm{acac})_{2}, \mathrm{OAm}$ & heat-up & $10 \mathrm{~nm} / \mathrm{spheres}$ \\
\hline $\mathbf{A g}_{78} \mathbf{P d}_{22}$ & $240^{\circ} \mathrm{C} / 1 \mathrm{~h}$ & $\mathrm{~W}(\mathrm{CO})_{6}, \mathrm{AgNO}_{3}, \mathrm{Pd}(\mathrm{acac})_{2}, \mathrm{OAm}$ & heat-up & $10 \mathrm{~nm} / \mathrm{spheres}$ \\
\hline $\mathrm{Pd}_{85} \mathrm{Ni}_{15}$ & $260^{\circ} \mathrm{C} / 40 \mathrm{~min}$ & $\mathrm{~W}(\mathrm{CO})_{6}, \mathrm{Ni}\left(\mathrm{CH}_{3} \mathrm{COO}\right)_{2} \bullet 4 \mathrm{H}_{2} \mathrm{O}, \mathrm{OAm}, \mathrm{TOP}$ & heat-up & $5 \mathrm{~nm} / \mathrm{spheres}$ \\
\hline $\mathrm{Pd}_{53} \mathrm{Ni}_{47}$ & $260^{\circ} \mathrm{C} / 40 \mathrm{~min}$ & $\mathrm{~W}(\mathrm{CO})_{6}, \mathrm{Ni}\left(\mathrm{CH}_{3} \mathrm{COO}\right)_{2} \bullet 4 \mathrm{H}_{2} \mathrm{O}, \mathrm{OAm}, \mathrm{TOP}$ & heat-up & $8 \mathrm{~nm} / \mathrm{spheres}$ \\
\hline
\end{tabular}



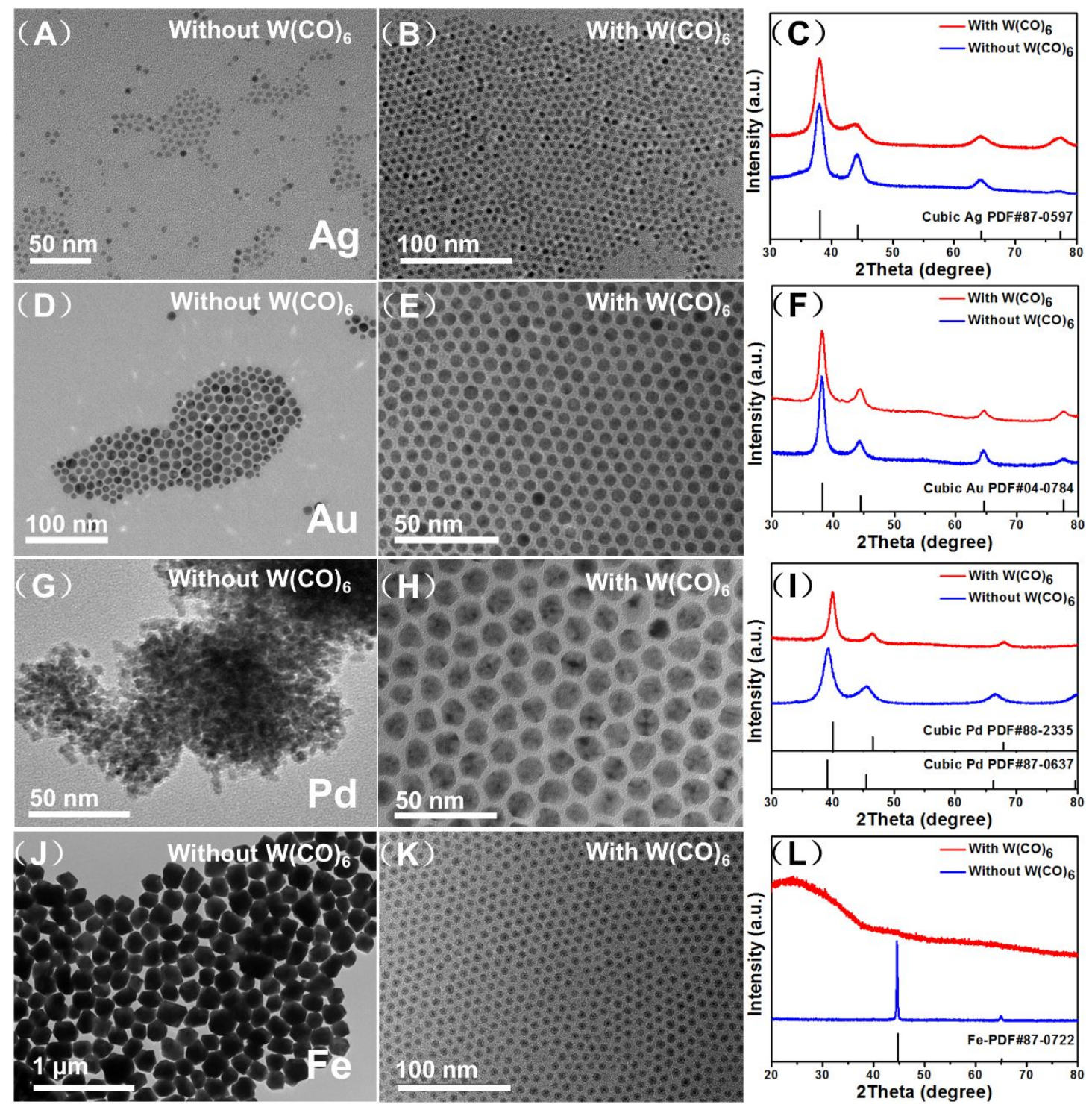

Figure S17. TEM and $\mathrm{XRD}$ results $(\mathrm{C}, \mathrm{F}, \mathrm{I}$, and $\mathrm{L})$ of the as-prepared $\mathrm{Ag}, \mathrm{Au}, \mathrm{Pd}$, and $\mathrm{Fe}$ nanoparticles in the absence (A, D, G, and J) and presence (B, E, H, and $\mathrm{K})$ of $\mathrm{W}(\mathrm{CO})_{6}$. 

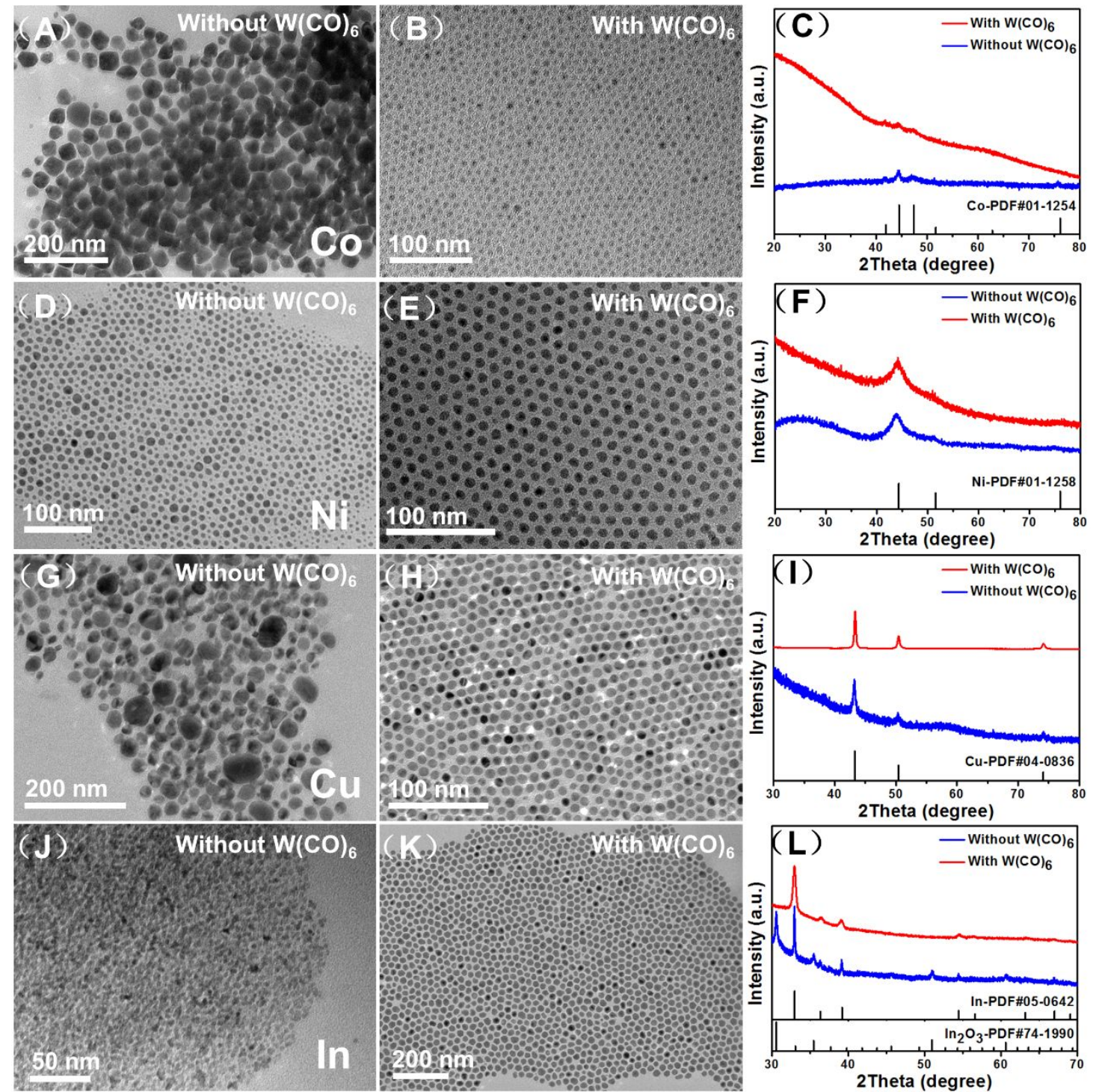

Figure S18. TEM and XRD results $(\mathrm{C}, \mathrm{F}, \mathrm{I}$, and $\mathrm{L})$ of the as-prepared $\mathrm{Co}, \mathrm{Ni}, \mathrm{Cu}$, and In nanoparticles in the absence (A, D, G, and J) and presence (B, E, H, and $\mathrm{K})$ of $\mathrm{W}(\mathrm{CO})_{6}$. 

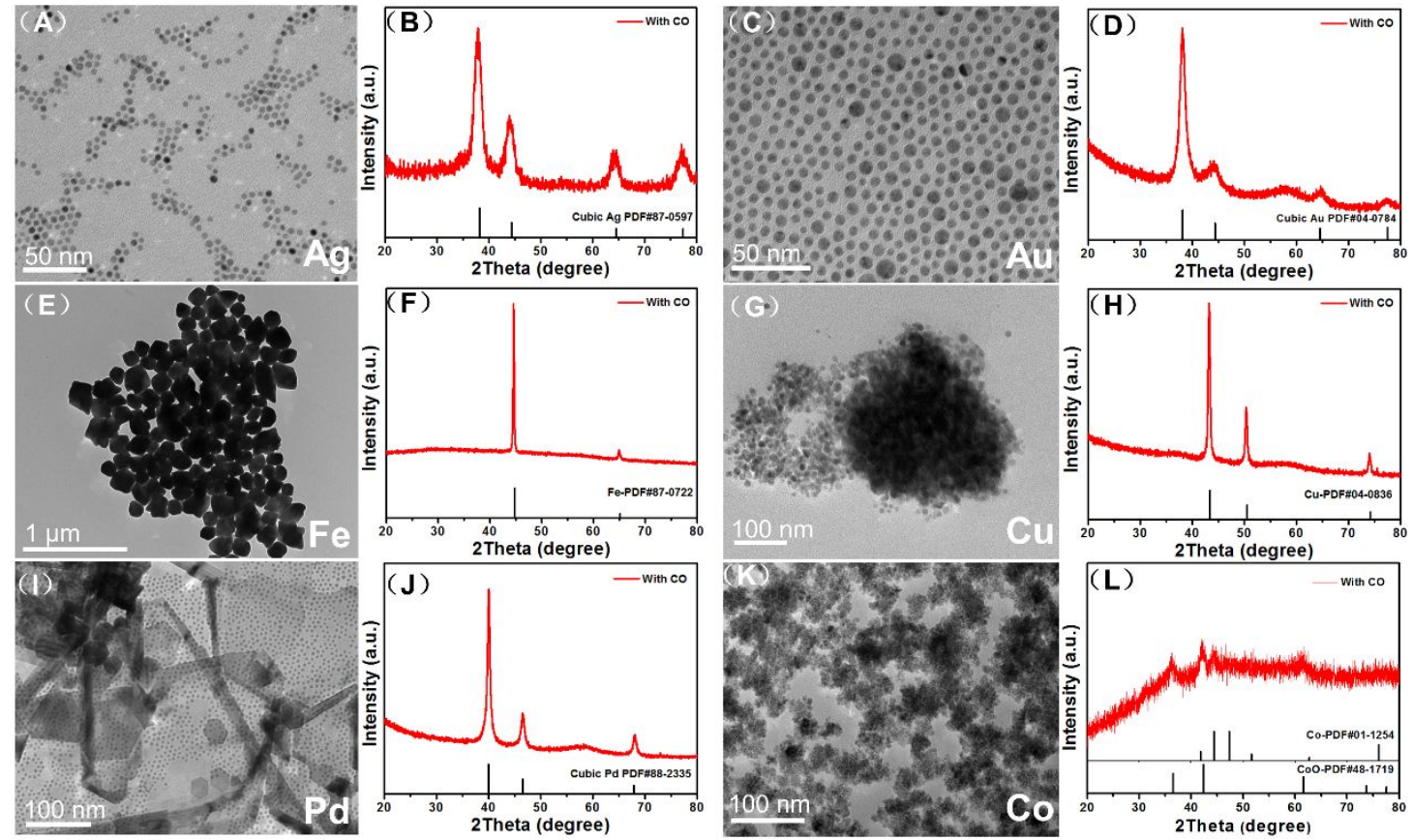

Figure S19. TEM images and XRD patterns of the as-prepared (A, B) Ag, (C, D) Au, (E, F) $\mathrm{Fe},(\mathrm{G}, \mathrm{H}) \mathrm{Cu},(\mathrm{I}, \mathrm{J}) \mathrm{Pd}$, and $(\mathrm{K}, \mathrm{L})$ Co nanoparticles by using $\mathrm{CO}$ gas to replace $\mathrm{W}(\mathrm{CO})_{6}$. 

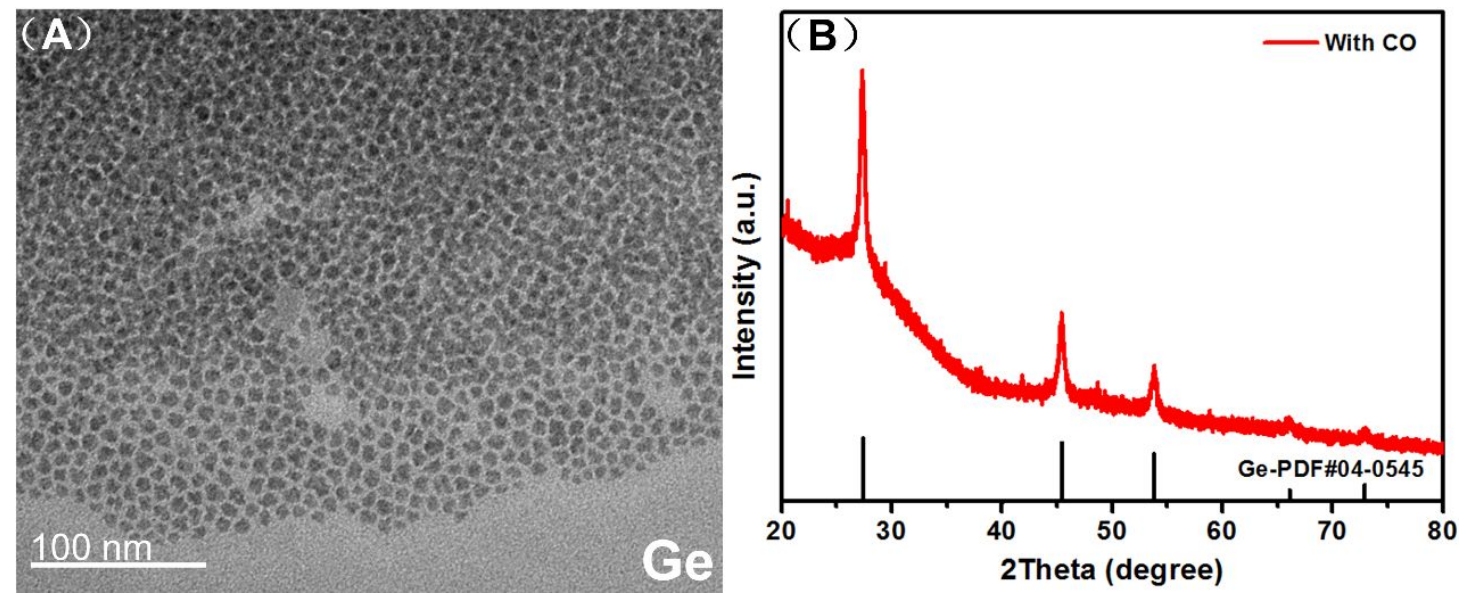

Figure S20. TEM image (A) and XRD pattern (B) of the as-prepared Ge nanoparticles by using $\mathrm{CO}$ gas to replace $\mathrm{W}(\mathrm{CO})_{6}$. 
Table S2. Redox potentials of different metal ion/metal pairs (vs. SHE).$^{1-3}$

\begin{tabular}{|c|c|c|}
\hline Metals & Reaction & Redox potential (E/V) \\
\hline $\mathrm{Au}$ & $\mathrm{Au}^{3+}+3 \mathrm{e}^{-} \rightleftharpoons \mathrm{Au}$ & 1.498 \\
\hline $\mathrm{Pd}$ & $\mathrm{Pd}^{2+}+2 \mathrm{e}^{-} \rightleftharpoons \mathrm{Pd}$ & 0.951 \\
\hline $\mathrm{Ag}$ & $\mathrm{Ag}^{+}+\mathrm{e}^{-} \rightleftharpoons \mathrm{Ag}$ & 0.800 \\
\hline $\mathrm{Cu}$ & $\mathrm{Cu}^{2+}+2 \mathrm{e}^{-} \rightleftharpoons \mathrm{Cu}$ & 0.342 \\
\hline $\mathrm{Ge}$ & $\mathrm{Ge}^{2+}+2 \mathrm{e}^{-} \rightleftharpoons \mathrm{Ge}$ & 0.240 \\
\hline $\mathrm{W}$ & $\mathrm{WO}_{3}+6 \mathrm{H}^{+}+6 \mathrm{e}^{-} \rightleftharpoons \mathrm{W}+3 \mathrm{H}_{2} \mathrm{O}$ & -0.090 \\
\hline $\mathrm{Pb}$ & $\mathrm{Pb}^{2+}+2 \mathrm{e}^{-} \rightleftharpoons \mathrm{Pb}$ & -0.126 \\
\hline $\mathrm{Ni}$ & $\mathrm{Ni}^{2+}+2 \mathrm{e}^{-} \rightleftharpoons \mathrm{Ni}$ & -0.257 \\
\hline Co & $\mathrm{Co}^{2+}+2 \mathrm{e}^{-} \rightleftharpoons \mathrm{Co}$ & -0.280 \\
\hline In & $\mathrm{In}^{3+}+3 \mathrm{e}^{-} \rightleftharpoons \mathrm{In}$ & -0.338 \\
\hline $\mathrm{Fe}$ & $\mathrm{Fe}^{2+}+2 \mathrm{e}^{-} \rightleftharpoons \mathrm{Fe}$ & -0.447 \\
\hline
\end{tabular}



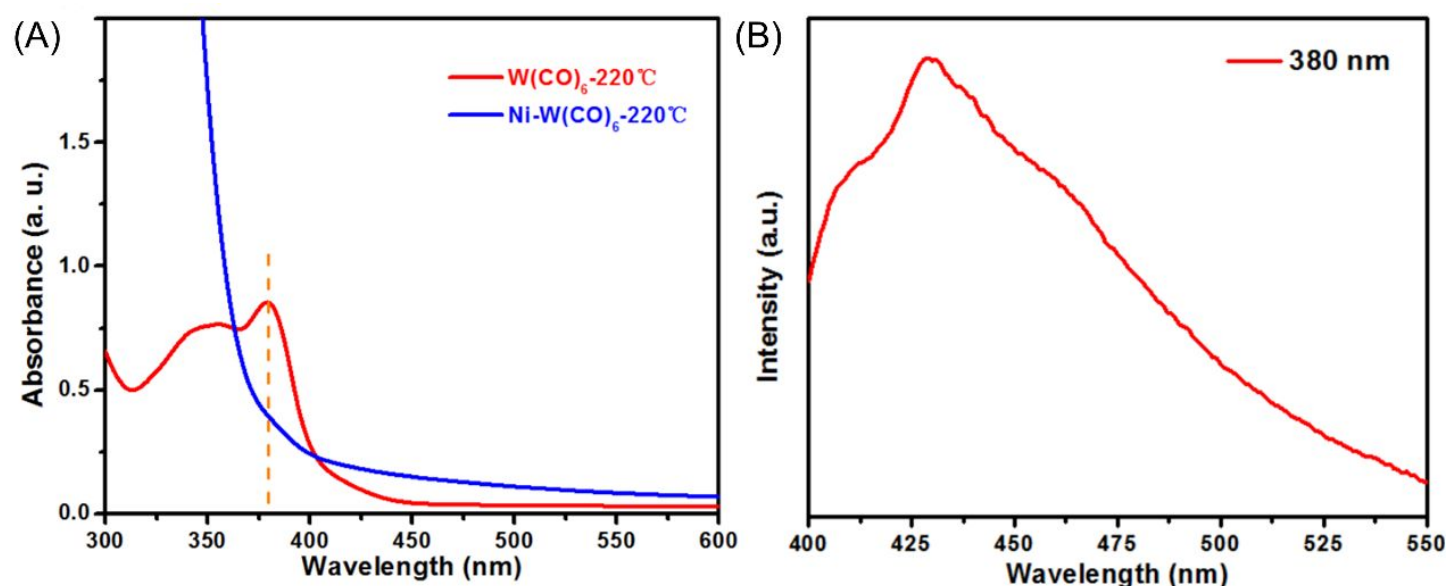

Figure 21. (A) UV-Vis spectra of the products obtained from $\mathrm{W}(\mathrm{CO})_{6}$ decomposition (red line) and synthesis of Ni nanoparticles (blue line) when temperature reaches $220^{\circ} \mathrm{C}$. (B) PL spectrum of the product obtained from $\mathrm{W}(\mathrm{CO})_{6}$ decomposition when temperature reaches $220^{\circ} \mathrm{C}$. 
Table S3. ICP-MS results of the as-prepared metal nanoparticles showing the molar percentages of metal and tungsten elements.

\begin{tabular}{|c|c|c|c|c|c|}
\hline Sample & Element & mol \% & Sample & Element & $\operatorname{mol} \%$ \\
\hline \multirow{2}{*}{$\begin{array}{c}\mathbf{A g} \\
\text { nanoparticles }\end{array}$} & $\mathrm{Ag}$ & 99.34 & \multirow{2}{*}{$\begin{array}{c}\mathbf{N i} \\
\text { nanoparticles }\end{array}$} & $\mathrm{Ni}$ & 98.32 \\
\hline & $\mathrm{W}$ & 0.66 & & $\mathrm{~W}$ & 1.64 \\
\hline \multirow{2}{*}{$\begin{array}{c}\text { Au } \\
\text { nanoparticles }\end{array}$} & $\mathrm{Au}$ & 99.87 & \multirow{2}{*}{$\begin{array}{c}\mathbf{C u} \\
\text { nanoparticles }\end{array}$} & $\mathrm{Cu}$ & 99.31 \\
\hline & $\mathrm{W}$ & 0.13 & & $\mathrm{~W}$ & 0.69 \\
\hline \multirow{2}{*}{$\begin{array}{c}\text { Pd } \\
\text { nanoparticles }\end{array}$} & $\mathrm{Pd}$ & 99.13 & \multirow{2}{*}{$\begin{array}{c}\text { In } \\
\text { nanoparticles }\end{array}$} & In & 97.57 \\
\hline & $\mathrm{W}$ & 0.87 & & $\mathrm{~W}$ & 2.43 \\
\hline \multirow{2}{*}{$\begin{array}{c}\mathbf{F e} \\
\text { nanoparticles }\end{array}$} & $\mathrm{Fe}$ & 96.88 & \multirow{2}{*}{$\begin{array}{c}\text { Ge } \\
\text { nanoparticles }\end{array}$} & $\mathrm{Ge}$ & 99.67 \\
\hline & $\mathrm{W}$ & 3.12 & & $\mathrm{~W}$ & 0.33 \\
\hline \multirow{2}{*}{$\begin{array}{c}\text { Co } \\
\text { nanoparticles }\end{array}$} & Co & 97.31 & \multirow{2}{*}{$\begin{array}{c}\mathbf{P b} \\
\text { nanoparticles }\end{array}$} & $\mathrm{Pb}$ & 99.13 \\
\hline & W & 2.69 & & W & 0.87 \\
\hline
\end{tabular}



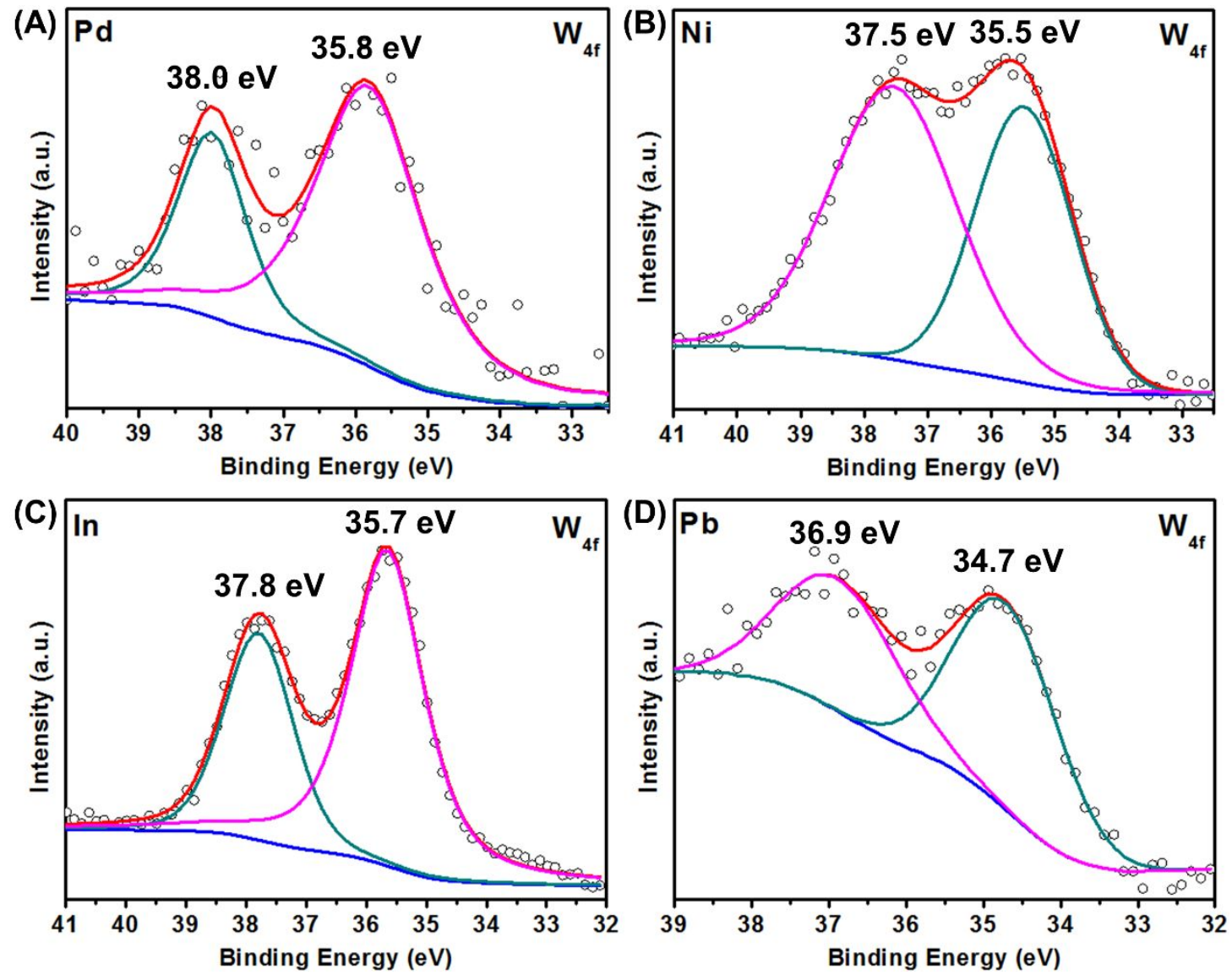

Figure S22. W 4f XPS spectra of the as-prepared (A) Pd, (B) Ni, (C) In, and (D) $\mathrm{Pb}$ nanoparticles in the presence of $\mathrm{W}(\mathrm{CO})_{6}$.

X-ray photoelectron spectra (XPS) results indicate that positive valence tungsten $\left(\mathrm{W}^{\mathrm{n}+}\right)$ is found in all samples (Figure S22). The two peaks $(38.0 \mathrm{eV} / 35.8 \mathrm{eV}$ for Pd, $37.5 \mathrm{eV} / 35.5 \mathrm{eV}$ for $\mathrm{Ni}, 37.8 \mathrm{eV} / 35.7 \mathrm{eV}$ for $\mathrm{In}$ and $36.9 \mathrm{eV} / 34.7 \mathrm{eV}$ for $\mathrm{Pb}$ ) are assigned to the binding energy of $4 \mathrm{f}_{5 / 2}$ and $4 \mathrm{f}_{7 / 2}$ of $\mathrm{W}^{6+}$, respectively. ${ }^{4}$ 

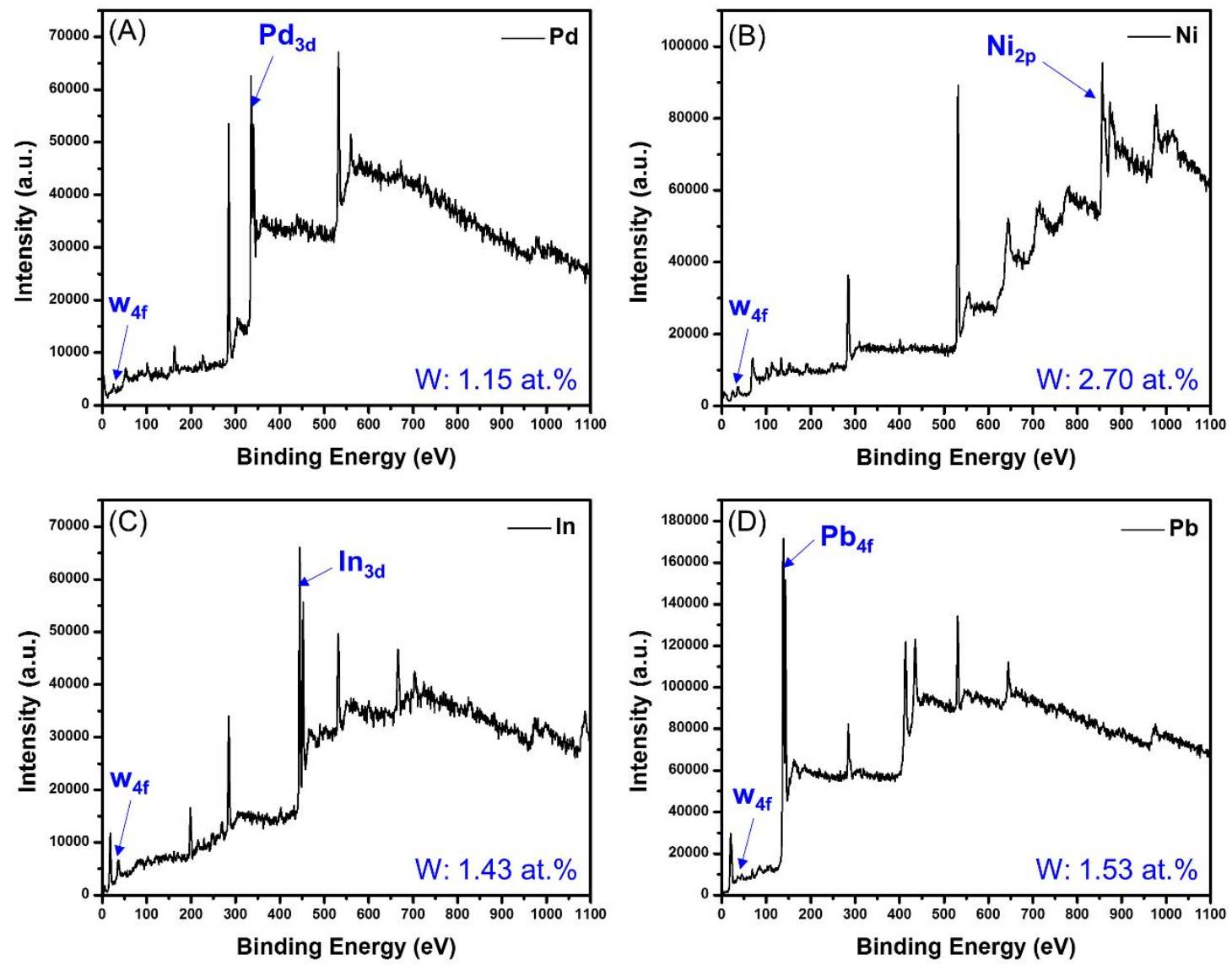

Figure S23. XPS spectra of (A) Pd, (B) Ni, (C) In, (D) Pb nanoparticles after ligand removal and corresponding atomic percentages of $\mathrm{W}$. 


\section{References}

(1) Milazzo, G., Caroli, S., and Sharma, V. K., Tables of Standard Electrode Potentials, 4th Edition, Wiley, Chichester, 1978.

(2) Bard, A. J., Parsons, R., and Jordan, J., Standard Potentials in Aqueous Solutions, Marcel Dekker, New York, 1985.

(3) Bratsch, S. G., Standard Electrode Potentials and Temperature Coefficients in Water at 298.15 K, J. Phys. Chem. Ref. Data, 1989, 18, 1-21.

(4) Moulder, J. F.; Stickle, W. F.; Sobol, P. E.; Bomben, K. D. in Handbook of X-ray Photoelectron Spectroscopy, Perkin-Elmer: Eden Prairie, MN, 1992, pp. 241. 